\title{
Political Chronicles
}

\section{Commonwealth of Australia January to June 2011}

\author{
JOHN WANNA \\ The Australian National University and Griffith University
}

\section{Embroiled in the Battlelines — Forging the Subtle Arts of Minority Government}

Amongst the inmates of the hung parliament a "new paradigm" of consensus politics was supposedly the order of the day. But the "new paradigm" was hardly proclaimed before the "old-style politics" of gladiatorial adversarialism, outright negativism and crass opportunism reasserted itself as the dominant form of politics. Almost every item the government proposed or endorsed was decried by the opposition, whilst the wily cross-benchers unsurprisingly looked to prevaricate and bargain. The opposition's main battering-ram, Tony Abbott, assumed the role of the "Abominable No Man": opposing everything for short-term political gain, even if a subsequent Coalition government would have to adopt similar policies (a short-term expedient ploy which eventually the serious media finally recognised). Abbott opposed the government on climate change, the resource rent tax, asylum seekers and off-shore processing, its deficit strategy and budgetary measures, health reform, plain packaging for tobacco, and some of the special disaster measures. One respected commentator, Paul Kelly, suggested that Abbott's "relentless political campaign is throttling the life from Labor" (Weekend Australian, 30 April - 1 May 2011). By contrast, the government frequently looked indecisive or rattled, and appeared to be making policy-on-the-run, often only to reverse or amend its decisions a few days later.

Political attention was distracted in the early months of 2011 by a series of natural disasters occurring over summer in Australia and the Asia-Pacific region - enormous floods hit North Queensland, Toowoomba, the Lockyer Valley and Brisbane in January (later flowing through to northern Victoria); in February two cyclones hit the coast Cyclone Yasi devastated Far North Queensland and Cyclone Carlos flooded Darwin; bushfires swept through Western Australia (south of Perth) in February; a massive earthquake registering 6.3 on the Richter scale wiped out much of central Christchurch in February, followed by much silt liquidification that damaged entire suburbs; and then in March a huge earthquake and tsunami hit the island of Honshu in Japan exploding a nuclear power station. Political endeavours were absorbed with various rescue efforts and clean-up exercises, and with encouraging public donations and with governments making exceptional payments to cover infrastructural replacements and compensation to those worst affected (in addition to the $\$ 3$ billion insurance bill). It was estimated the total cost of the Australian disasters had reduced GDP by $\$ 9$ billion 
alone. To help communities and infrastructure rebuild after the Queensland floods, a special federal "flood levy" was announced in January to raise $\$ 1.7$ billion in one year in order to reduce the risk of the Commonwealth budget remaining in deficit for longer than had been anticipated (i.e. by 30 June 2013). The levy was imposed solely on income earners in higher brackets and not more broadly spread, and was predictably dubbed another "great big new tax" by the opposition.

As parliament resumed it was evident the government was adopting a small-target strategy, avoiding the "big" confrontational issues to enable the parliament to process routine legislative business. By the mid-winter break the government had passed some 150 pieces of legislation (without a single defeat), much of it amendment legislation and some not very significant, but nevertheless a resolute record of achievement many would have considered beyond them. Its more contentious legislative initiatives were the subject of much back-room negotiation and were scheduled for later in the parliamentary calendar. The opposition did not make the job of running parliament easy, regularly calling divisions, refusing automatic "pairs" on MP attendance and on votes, and attempting to block procedures at every opportunity. But occasionally they went too far. For instance, on 31 May the Speaker of the House of Representatives, Harry Jenkins, was almost forced to resign after disciplining a Liberal member, Bob Baldwin, and seeking to suspend him from the chamber. It was a routine matter, but when his ruling was challenged by the opposition, the government lost the ensuing vote by 71-70 with Rob Oakeshott joining with the opposition in dissent of the ruling. The defeat was essentially a want of confidence in the Speaker and left Jenkins with no alternative but to "consider his future" after question time (i.e. indicating he intended to resign). The opposition then realised it had over-stepped the mark, and faced the prospect of having to offer one of its own members as Speaker. Suddenly, the Opposition leader Tony Abbott jumped to his feet and somewhat disingenuously offered his glowing, "total confidence" in the Speaker remaining in the post (much to the relief of the Prime Minister Julia Gillard who seconded the motion with "great pleasure"). A little nonplussed, Jenkins survived thanks to a rare moment of bipartisanship, but the incident demonstrated how precariously poised the forty-third parliament remained.

\section{Policy Challenges - Suddenly Everything Seems Contentious}

Outside parliament the government was finding it difficult to make much headway on any number of contentious policy areas or where solutions were hard to broker. The mining tax was stalled in negotiations with the industry and the various mining associations. The opposition had announced its intention not only to oppose the measure but to repeal it if implemented, yet it was not even clear the government could manage to get its resource rent tax through the House of Representatives. A proposed mandatory scheme to force problem gamblers to pre-commit an amount they could afford to lose was announced but immediately raised the ire of the clubs and hotels who had become increasingly dependent on poker machine income (as had state and territory Treasuries). In April an advertising campaign (similar to the mining tax campaign) was launched by the clubs attacking the proposed measure, claiming it was a tax on footy and an invasion of people's liberties. The ads posed the question: "who voted for a licence to punt". When state and territory governments refused to comply with the federal request to implement a pre-commitment scheme, Gillard's problems intensified because her government rested on support from Andrew Wilkie who had threatened to bring the government down if it did not introduce such a policy. 
Milk wars erupted as the larger supermarkets began "aggressive discounting" selling milk for as little as $\$ 1$ per litre, leading to many complaints from farmers and regional centres that the farm-gate price was unsustainable. Retailers began to fight against the import of goods ordered through the internet from overseas, which they claimed was costing them sales and jobs because it was exempt from GST. The government estimated that such sales were worth around $\$ 5$ billion, costing some $\$ 500$ million in lost GST, but it chose not to act. Bookstores such as Borders and Angus and Robertson suddenly began to close their retail outlets (up to eighty-five) as consumers turned away from buying local books and sourced their reading from overseas. Again controversy arose over protecting local content and production although the government remained unmoved. More headway was made on compulsory plain packaging for tobacco products after the Health Minister Nicola Roxon announced in April that the government would be proceeding with legislation to enable this. Her stance was immediately met with a multi-million-dollar advertising campaign by tobacco companies to defeat the proposal, coupled to a mooted High Court case to claim the policy would be a violation of their freedom of speech. The prospects for gay marriage came and went as the government, under pressure from the Greens, announced in March it would allow the two territories to legislate without fear of a Commonwealth veto; however, the issue stalled after a fierce anti-same-sex marriage backlash from the Labor caucus against Julia Gillard (who personally opposed the move but who had compromised with the Greens). Gay marriage would remain a salient issue especially with the Greens and associated inner-city communities.

Off-shore processing of boat-people seeking asylum was in total disarray, as one after another of the government's preferred processing locations proved either to be unworkable or were soon discredited. Many of these supposed venues were announced piecemeal, typically in desperation, without much consultation with the nation concerned. Gillard personally announced in 2010 that the impoverished new nation of East Timor would agree to process asylum seekers (ostensibly after talking to the president Jose Ramos-Horta but not to the government headed by Prime Minister Xanana Gusmao). The East Timorese, seemingly faced with an apparent fait accompli, politely declined Australia's offer. Following a series of riots in April by long-term detainees in detention centres, the government proposed in May that the tiny island of Manus located on the equator, but part of Papua and New Guinea be used, but the centre had fallen into disrepair and was non-functional. The former government's processing centre at Nauru was ruled out by Gillard on the grounds that she had said it was inhumane while in opposition (but apparently not ruled out by all her cabinet). Finally, the most audacious announcement was that a refugee-swap with Malaysia would be made as a discouragement to people smugglers, with 4,000 largely destitute Burmese Buddhists (regarded as "genuine asylum-seekers") being exchanged for 800 largely Afghan or Pakistan Moslems who would be sent to the Malay Peninsula without much assistance or services. The initial sticking problem was Malaysia's unwillingness to agree to the terms of the deal; but later the fact that Malaysia was not a signatory to the UN refugee charter was a much more salient obstacle. Thailand and the Solomon Islands were also mooted as likely processing destinations. In May when the Immigration Minister, Chris Bowen, announced that the next boat-loads of asylum seekers would be processed in Malaysia, the government's authority was challenged in the High Court (which immediately granted an injunction against the proposed action) by lawyers acting for the detained boat-people. 
The vexed carbon tax issue also dominated the year. Initially, the government's announcement in February that it would introduce a temporary carbon tax (until an emissions trading scheme could be established in 2015) of some unspecified amount was regarded as a backflip and a deliberate deception, as Julia Gillard had unambiguously ruled out such a tax in the days before the last federal election. Gillard announced the proposal from Parliament House flanked by Green senators and House Independents, who would deliberate on the exact policy details in a special cross-party parliamentary committee (on which the opposition declined to participate). The uncertainty was amplified because initially no economic modelling was released (about the costs, economic growth projections, investment effects, lost jobs etc.), the starting tax price was not disclosed and the compensation arrangements were not announced. Speculation over the price for carbon ranged from \$23-40 per tonne, with most considering it would be at the lower end of this range (although at times the government looked to be plucking a number from thin air). In this fluid environment both unions and sections of business looked nervous and began seeking guarantees and compensation. The government eventually agreed it would over-compensate to offset the cost on industries and on medium-lower income households. The opposition predictably claimed the government had no mandate to introduce such a new tax (it was, according to Abbott, a "post-election deceitful rationalization" - Australian, 16 March 2011), and insisted that the government ought to call an early election to resolve the issue. A widespread populist fear campaign erupted, leading to many local protests and on 23 March a mass demonstration outside Parliament House at which Tony Abbott spoke to rally the crowd. At this demonstration Gillard was called "Juliar" and "Bob Brown's bitch" while other signs screamed "you lied!", "ditch the witch!" and "reject junk science". Meanwhile the right-wing shock-jock Alan Jones said she should be tied in a chaff-bag and dumped out at sea, along with Senator Bob Brown. It was dubbed the so-called "people's revolt" but most attendees seemed to be far right splinter groups (including Pauline Hanson) organised by the Consumers and Taxpayers Association. In response the government countered the populist campaigns by launching its own pro-tax advertisements in June.

At a COAG meeting in February, an "in principle" agreement was made with the states and territories for the Commonwealth to fund all primary care and 40 per cent of public hospitals (helped by the promise of an additional $\$ 16$ billion funding). The Prime Minister and territorial chief ministers signed off on the deal (which reduced Commonwealth funding from the 60 per cent proposed by the former PM Kevin Rudd but left the GST payments untouched), but many states refused to initiate progress towards the agreement, instead arguing over the rights of states to manage "their" hospital systems (which was often code for not performing as the Commonwealth insisted). Local health regions/areas were supposedly to be established in each jurisdiction (as service providing and purchasing boards) but, as the July 2011 deadline approached, few states had taken any real steps to establish these funding and coordinating bodies. The states seemed motivated in dragging the chain either by a preference to maintain state control over their public hospitals or a reluctance to decentralise and de-bureaucratise their health administrations. The stand-off continued.

Finally, the government looked entirely caught out in late May and early June by a scandal over the brutal slaughtering of cattle in Indonesia according to supposed Halal ritual killing. An episode of the ABC's Four Corners showed horrific scenes of cattle being slashed with knives, beaten with bars, and killed in the most cruel of manners, often taking minutes to die. After much public outrage and some initial dithering about 
setting up an inquiry, the Agricultural Minister, Senator Joe Ludwig, placed a temporary suspension on the lucrative live cattle export industry (worth some $\$ 350$ million per year). His hand had been forced not by the issue, but by a revolt by twenty members of Labor's own caucus appalled by the brutality. Indonesia was Australia's largest export market for live cattle (with some 60 per cent of sales, or approximately 520,000 cattle per year mostly coming from Northern Australia). Predictably, northern cattle producers complained about the ban, and with huge herds and no local abattoirs, were facing major losses of income and the problem of what to do with the cattle. Begrudgingly the minister initially offered $\$ 3$ million in compensation to affected producers, covering their costs for thirteen weeks. After both Foreign Affairs and the Prime Minister's department were brought in to help resolve the crisis, the general ban was eventually lifted for a select group of accredited abattoirs that used modern killing techniques. The blanket ban and panicked response made the government look incompetent in the eyes of many in the meat industry and politicians from Western Australia and the Northern Territory. The opposition never supported a blanket ban.

\section{The "Responsible" Budget of 2011-12}

The government produced its "responsible" budget in May, declaring a deficit for the year of $\$ 22.6$ billion but still intending to be back into surplus by June 2013 (by $+\$ 3.5$ billion). It was a "moderate austerity" budget, with little scope for new spending or growth in the public service (maintaining the low growth cap of 1 per cent on expenses until a healthy surplus was achieved), and including cuts to departmental expenses, and discontinued or lapsed programs. But the cuts were not as deep as the government had been promising - leading one newspaper to depict the Treasurer, Wayne Swan, as Crocodile Dundee with a pen-knife under the heading: "That's not a knife, Treasurer" (Australian, 11 May 2011). Indeed, Swan did not appear confident in his delivery of the budget and the government had largely stopped selling the document within a few days. A number of selected "savings" measures were announced, including closing tax loopholes and tightening eligibility criteria, supposedly saving the budget some \$22 billion over four years. The dependent spouse rebate was abolished, the discount rate for up-front repayments for higher education was halved, fringe benefits on company cars was tightened, the indexation of some family payments was frozen, work-tests and the definition of disability was tightened, work obligations were increased for those not working on benefits, the solar rebate scheme was further tightened, and Defence was cut by around $\$ 4.3$ billion over the four-year forward estimates costing some 1,000 administrative jobs. The main winner in the budget was additional funding for mental health, especially for early intervention strategies. The government claimed that $\$ 2.2$ billion was available but only around $\$ 1.5$ billion was new money (the rest was clawed back from existing programs).

Tony Abbott presented the budget reply speech by largely ignoring the government's measures, and instead presenting his own plans for future budgetary directions. These included a "tough love" approach to social welfare, no new taxes or carbon levy, a centralised health and education funding system governed by local boards, more direct action environmental initiatives, harder stance on border protection, and a withdrawal from the National Broadband Network, using the funds for other essential infrastructure. Labor predictably complained that Abbott's speech had not addressed "their" budget but had been a political spiel directed at the electorate. The Coalition indicated in June that it would block all the savings measures in the budget, perhaps eroding $\$ 10$ billion from the bottom line and making the projected surplus all that much harder to secure. Swan complained that the opposition 
was "wrecking" the budget for short-term gain (see Australian, 7 June 2011). However, after the parliamentary debates and estimates processes, the Coalition meekly allowed the budget to pass in both houses, because it could see no real political mileage in blocking the bills (and the government had threatened to recall parliament for an extra sitting day (Friday before the winter break) if its budget was not passed (throwing out MPs' travel arrangements).

\section{Poor Polling, Low Credibility and Scandals Dog Julia Gillard's Leadership}

Labor's leadership woes continued, despite Julia Gillard's protestations that the government had to be more decisive and focus on delivery. Polls often showed the Coalition enjoying a 5-10 per cent lead over Labor in two-party preferred terms with the Coalition recording around 52-55 per cent support compared to Labor's 48-45 per cent (see Newspolls). Labor's primary vote frequently sat on 30-32 per cent. Many ministers were forced to publicly defend Gillard's leadership, claiming she was doing a good job in difficult circumstances and that things would improve once a few controversial issues were behind the government.

There was intermittent talk of Kevin Rudd making a come-back, as he continually remained more popular in the polls than the Prime Minister, often by a considerable margin. He had rebuilt his image through his work over summer helping clear flood damage in Brisbane, and through intense activity on the international stage. He kept repeating he was focused on discharging his duties as foreign minister, but was shameless in self-promotion. Paul Kelly announced in April that Gillard's leadership was being "boxed in by Rudd on the rebound" with Gillard's credibility "in tatters" and Labor's caucus watching on with "a mixture of horror, fatalism and confusion" (Weekend Australian, 9-10 April 2011). Nevertheless, the powerful right faction remained vehemently opposed to his return to the top job, sometimes suggesting either Stephen Smith or Bill Shorten would be their preferred candidate if anyone in the party ran against Gillard. Leadership speculation remained a constant distraction adding to the apparent debilitation of the government.

There was even talk of popular Labor leaders from the states being drafted to fill the leadership vacuum at the federal level. Peter Beattie, Steve Bracks and Bob Carr were the most favoured to make the switch in media speculation, with some support for the recently defeated Kristina Keneally (Weekend Australian, 25-26 June 2011). Beattie was even forced to rule out re-entering politics to quell the obsessive media interest.

\section{Oppositional Manoeuvrings}

Continued jockeying for Julie Bishop's position as deputy leader continued to percolate beneath the surface, as did complaints about Hockey's capacities as shadow Treasurer. Bishop and Abbott had a major disagreement about aid funding to moderate Islamic schools in Indonesia. Abbott was increasingly dismayed by the internal squabbling and imposed his authority to calm tensions and remind shadow ministers to focus on their own portfolio responsibilities. Besides the top leadership group, other senior opposition spokespeople were encouraged to take a higher profile to broaden the Coalition's image (including Scott Morrison, Andrew Robb and Greg Hunt). There were media reports of "scouts" among the Liberal party-room canvassing support for a return to the leadership of Malcolm Turnbull; but these were followed by the leaking of an internal email from the party whip Warren Entsch complaining of Turnbull missing crucial parliamentary divisions. The media also ran reports of the Nationals' Senator Barnaby Joyce musing over standing against the independent Tony Windsor in the seat of New England (where Barnaby had grown up). However, when party rules prevented him 
from nominating for a seat in another state, he began eyeing the Queensland seat of Maranoa held by the long-term but not very prominent Bruce Scott (who had served eight parliamentary terms and risen to be Veterans' Affairs Minister 1996-2001). With a combined LNP arrangement in the Coalition in Queensland, Joyce had fewer procedural problems if he chose to nominate for Maranoa.

Finally, in late June, a close contest for the position of Liberal Party national president brought outright conflict to a head in the party. The incumbent Alan Stockdale (the former Victorian Treasurer) had re-nominated for the post to the dismay of some, when Tony Abbott approached former Howard Defence Minister Peter Reith to stand against him, promising his support. In the ensuing battle for the presidency, Reith was considered the narrow favourite but lost in a federal council ballot by one vote (57 to 56). Tony Abbott did a show-and-tell vote captured on TV, showing Alan Stockdale he had voted for him not Reith (presumably because of pressure from federal director Brian Loughnane and his wife Peta Credlin who worked for Abbott). The almost senseless shenanigans led many to question the internal process of the party not to mention the judgements and conflicting loyalties of Abbott himself.

\section{Out-going and In-coming Appointments in Government}

In February Julia Gillard's chief of staff, Amanda Lampe (from the New South Wales Right), was replaced by her senior adviser Ben Hubbard. It was claimed that relations in the PM's office had become dysfunctional, were not always harmonious, and that Lampe had spent more time on spin than substance or the consequences for implementation. She was, however, appointed as a special adviser to the PM for an additional four months on a salary equivalent to over $\$ 150,000$ p.a. Lampe was for a while touted as the next ALP national secretary to replace Karl Bitar who was widely blamed among Labor members for the poor campaign of 2010; however, Lampe's faction refused to support her and instead in April Julia Gillard nominated George Wright (a non-factional, former ACTU official and Rudd staffer) who won the post with cross-factional support. Professor Warwick McKibbin, a frequent critic of government policy, was not re-appointed to his position on the board of the Reserve Bank, after serving two terms. His replacement was John Edwards - an economist and former adviser to Paul Keating.

In February the Defence Minister, Stephen Smith, attempted to sack the head of the Australian Defence Force Academy, Commodore Bruce Kafer, ostensibly for disciplining a young female cadet who had just made allegations of sexual degradation (a fellow male cadet had broadcast them having sex on a Skype webcam to his colleagues). When Smith heard that the woman was disciplined for minor breaches at an internal tribunal hearing and was told to address her cadet division to apologise because her classmates were very angry about her going public with the complaint, he said the incident was "completely insensitive to completely stupid" believing that the senior officers had grievously mishandled the matter, regarding it as a minor misdemeanour. Smith apparently had a major fall-out with the Chief of the Defence Force, Air Marshal Angus Houston, after the minister demanded Houston sack Kafer. Houston however merely stood Kafer down on paid leave while a series of investigations were conducted including an AFP inquiry. Smith had also been highly critical of Defence's operational readiness after three naval landing craft (the ships Manoora, Kanimbla and Tobruk) were all unavailable to assist Queenslanders after Cyclone Yasi. In June it was announced that Angus Houston would retire as Chief of Defence in July, being replaced by General David Hurley (Army), whose own 
successor in three years time was also named as part of a long-term succession policy (Air Marshal Mark Binskin).

Around March a number of senior executive changes took place in the public service (some had been announced around Christmas). Both long-serving secretaries Ken Henry and Jeff Harmer retired from their positions at the head of major Commonwealth departments. Ken Henry (Treasury Secretary from 2001-2011) was widely credited with managing Australia's timely stimulus response in the global financial crisis - the so-called "cash splash" (famously urging the government to "go hard, go early, go households" with a series of stimulus measures). Jeff Harmer (FaHCSIA) had a distinguished and influential career in social policy and had served for over eight years as secretary in two portfolios. Both had recently undertaken major reviews for the government (Henry on tax - the Future Taxation System Review and Harmer on pension reforms and as a member of the Henry review). Henry was subsequently appointed as a special advisor to the Prime Minister in June. Fin Pratt (the secretary of Human Services and previously Centrelink) replaced Harmer in FaHCSIA and Martin Parkinson (a former deputy secretary in Treasury and then secretary of Climate Change) replaced Henry in Treasury. Kathryn Campbell was appointed the new secretary of Human Services while Parkinson's deputy Blair Comley (exTreasury) was elevated to the secretary's job in Climate Change. Later, in June, Dr Don Russell (a former Keating economic adviser) was appointed to head the Department of Innovation (replacing Mark Patterson); Paul Grimes (ex-Finance and Prime Minister andCabinet) was appointed to head the Department of Sustainability, Environment, Water, Population and Communities (replacing Robyn Kruk who was moved to the National Mental Health Commission; and a former adviser to Bob Hawke, Rod Sims, was appointed to head the Australian Competition and Consumer Commission.

\section{Desideratum to End}

Towards the end of the period, the North Queensland Independent Bob Katter announced that he was forming a new political party — the "Australian Party" (later officially named "Katter's Australian Party") because he had come to the conclusion that the days of stand-alone independents had passed. His bravado did not excite his fellow federal cross-benchers, but did appeal to a few state mavericks (especially in Queensland where a Katter-inspired "Queensland Party" was already being founded to contest the next state election). At the announcement of the party, Katter was all bluster saying that he was going to "come after" the mainstream parties and overwhelm them "with tanks and artillery ready to go". His policy platform was relatively populist defending farmer property rights, reaffirming the right to shoot and fish, advocating food security and fair food prices for producers, supporting local community autonomy and opposing the sale of state assets (his platform did not avow the racist or xenophobic sentiments associated with the former populist One Nation party). Katter tried to woo the rural electorate with statements such as you should be able to boil the billy where you chose and that ordinary Australians did not want to be told what they could and could not do. Most commentators saw his rebranding as potentially dividing the conservative vote, while one former conservative state premier described the new party as "One Nation with a hat".

The period ended with the parliamentary mid-winter ball - for politicians, staffers and journalists. This year the ball was held around the first anniversary of Kevin Rudd's deposition - meaning that the Labor leadership and the possibility of a Rudd come-back was a perpetual feature of media commentary. After a blitz of media 
appearances by the former PM designed to keep the leadership issue alive, Christopher Pyne quipped that the "only thing Kevin Rudd hasn't done is ride a bicycle into question time, blowing a vuvuzela, demanding the leadership back" (Australian, 20 June 2011). His humorous quip did nothing to stem the unease shared by much of the Gillard ministry (and many in caucus) increasingly anxious over her decline in the polls.

\title{
New South Wales
}

\section{January to June 2011}

\author{
DAVID CLUNE \\ Department of Government and International Relations, The University of Sydney
}

\section{Electricity Outage}

The repercussions of the government's controversial attempt to sell off electricity assets dominated politics in the early part of 2011. Resistance within the ALP had prevented wholesale privatisation of the electricity industry but the government was able to sell retail assets. This was to be done in two tranches. Three electricity retailers, three power station development sites and the output from two generation companies were to be sold first, followed by the output from two further generators. The sale of the first tranche in December 2010 was so controversial that the Legislative Council's General Purpose Standing Committee Number One, chaired by Reverend Fred Nile, decided to investigate the transactions. Premier Kristina Keneally attempted to thwart the investigation, although publicly she denied this was her motive, by proroguing parliament. After a long constitutional wrangle, the inquiry finally proceeded although some uncertainty remained about its powers.

The Committee's report was released on 23 February. It found that:

- "Contrary to evidence given by the Premier", Parliament was prorogued for the "specific purpose" of frustrating the Inquiry.

- The proceeds of the sale were "likely to be significantly less" than the figure provided by Treasurer Eric Roozendaal.

- The government had been left with major and potentially expensive risks "relating to the electricity market, coal supply and the costs of operating and maintaining generators".

The Committee recommended that the sale be "immediately rescinded", that after the March election the incoming government establish a full judicial inquiry into the transactions, and that legislation be passed to prevent privatisation of electricity assets without the approval of both Houses of Parliament (New South Wales Legislative Council, General Purpose Standing Committee No 1, Final Report on the Gentrader Transactions, February 2011). Halfway through the Committee's inquiry, the government announced that the second tranche sale would not be proceeding as no bids had been received (Sydney Morning Herald, 1 February 2011).

The electricity sale fiasco had a devastating effect on the government's already abysmal prospects for the election. For a public already disenchanted with a seemingly never-ending series of Labor scandals and disasters it was the last straw. Keneally's 
popularity, already on the decline, never recovered. Her "cleanskin" image was irretrievably tarnished. A Newspoll released on 23 February had the ALP on a primary vote of 23 per cent and two-party preferred of 38 per cent. Opposition Leader Barry O'Farrell led Keneally 47 per cent to 32 per cent as preferred premier (Australian, 23 February 2011).

\section{The Election}

The government's campaign for the 26 March election was based not on an attempt to win but to minimise the size of the defeat. It had three major elements. At an unofficial "soft launch" in Sydney's west on 6 February, Keneally frankly admitted the government had lost its way and apologised to voters. In an attempt to retain the votes of traditional ALP supporters, she concentrated on cost-of-living pressures and promised a $\$ 913$ million "Fairness for Families" package to ease the burden. The Premier hit the road in her "Fairness for Families" bus, dispensing charm and largesse. Instead of concentrating on marginal seats as would be the case in a normal campaign, Keneally spent much of her time in traditional Labor areas such as Sydney's western suburbs, the Illawarra and the Hunter. Another element of Labor's strategy soon became clear: to make the campaign a contest between the polished and photogenic Keneally and the uncharismatic O'Farrell. The Premier sought to engage with the Opposition Leader as often as possible in the hope that he would crack under pressure. Keneally repeatedly berated O'Farrell for being without substance and policies. The third part of Labor's strategy was based on frightening wavering ALP supporters back into the camp. The government became increasingly negative as the campaign progressed and the polls showed little improvement in its position. While in public Keneally remained gamely optimistic, ALP officials and MPs were conceding the party faced defeat. Voters were urged not to give a "blank cheque" to the Liberals. Labor maintained that O'Farrell had a secret agenda to dismantle the public sector and community services (Sydney Morning Herald, 7 February 2011, 19 March 2011; Australian, 7, 24 February 2011, 8, 12-13 March 2011).

The Coalition campaign projected a business-like determination to get on with the task of "making NSW number one again". A policy manifesto released by the Opposition detailed a five-point plan: rebuilding the economy; re-establishing quality services in health, education, transport and community safety; renovating infrastructure; restoring accountability to government; protecting the local environment and returning planning powers to the community <www.nsw.liberal.org.au/images/ stories/documents/policy-document-sept-web-101110.pdf>. The Opposition marketed its programme as practical, affordable and achievable. A low-key campaign suited the Liberals who were so far ahead they needed no more momentum. The unstated aim was to come to office unencumbered with as few costly commitments as possible. The challenge was to avoid complacency and disasters. Although he could not match Keneally's charm and vivacity, O'Farrell proved to be an effective if unexciting campaigner. He deliberately cultivated the image of being more about unglamorous reality than spin. O'Farrell calmly allowed the Premier's attacks to bounce off and moved relentlessly forward undistracted from his message. As well as campaigning in the marginals, the Opposition Leader spent much time in Labor's heartland (Australian, 21 February, 17 March 2011; Sydney Morning Herald, 3, 12 March, 20 June 2011).

The Greens were optimistic about securing representation in the Assembly for the first time by winning the seats of Balmain and Marrickville from Labor. Unlike previous elections, they did not direct preferences to the ALP in the Upper House and 
in a significant number of Assembly seats. The Greens appealed for support in the Legislative Council to prevent a Coalition government gaining control with the backing of conservative minor party MLCs. The Greens' campaign hit a major obstacle when it was revealed that their candidate for Marrickville, local Mayor Fiona Byrne, had supported a Council boycott of Israel in line with the Boycott, Divestment, Sanctions (BDS) movement. The media reported that she had committed herself to push for a similar ban on a state-wide basis. Byrne denied this but was forced to back down when a journalist produced a tape of a media conference where she had made such a statement (Sydney Morning Herald, 12, 15 February 2011; Australian, 15, 22, 23, 2627 March 2011).

The final polls showed virtually no change since the beginning of the campaign. A Newspoll published on election day had Labor's primary vote at 23 per cent and the Coalition's at 50 per cent. The two-party preferred vote for Labor was 36 per cent. O'Farrell was preferred Premier for 48 per cent compared to 32 per cent for Keneally. The last Nielsen and Galaxy polls had broadly similar results (Australian, 26-27 March 2011; Sydney Morning Herald, 26 March 2011; Daily Telegraph, 25 March 2011).

The Coalition won government on 26 March with a two-party preferred vote of 64.2 per cent, a swing of 16.9 per cent. Both were post-war Australian records. Its primary vote was 51.2 per cent compared to Labor's 25.6 per cent. The Green primary vote was 10.3 per cent, an increase of only 1.3 per cent on 2007 . The Greens did, however, win Balmain. Independents retained Sydney (Clover Moore), Lake Macquarie (Greg Piper) and Northern Tablelands (Richard Torbay). The Coalition won 69 of the 93 electorates, an increase of 34 . It held 41 of its seats with margins above 20 per cent. As remarkable as the size of the swings, was where they took place. The Liberals won a swathe of seats in western Sydney and made significant inroads in the Hunter and Illawarra. In the bush, The Nationals virtually annihilated the ALP and defeated three of four sitting Independents. The Coalition increased its representation in the Legislative Council by four to nineteen, leaving it dependent on minor party support. The Greens increased their numbers by one to five (for full details of the results see $<w w w . e l e c t i o n s . n s w . g o v . a u / p a s t$ results/state_elections $>$ ).

Although Keneally fought a tough campaign and kept her nerve until the end, it made virtually no difference to the result. The electors had already made up their minds and were not going to be swayed. O'Farrell conducted a well-planned, well-executed, error-free campaign. In this contest, the voters preferred a "safe pair of hands" to a glamorous personality.

\section{A Hundred Days}

Barry O'Farrell became the forty-third Premier of New South Wales on 28 March 2011. His twenty-one Ministers (including five women) were sworn in on 3 April. Nationals Leader Andrew Stoner became Deputy Premier and took on a new Ministry of Trade and Investment and Regional Infrastructure and Services. The huge increase in the number of Liberal MPs led to the Nationals having seven Ministers instead of eight as in the shadow cabinet. Most shadow ministers kept their responsibilities although three (Greg Aplin, Catherine Cusack and Melinda Pavey) were dropped. Liberal Deputy Leader Gillian Skinner became Health Minister, Mike Baird Treasurer and Gladys Berejiklian Transport Minister. The last two are seen as potential successors to O'Farrell, with the Premier said to favour Berejiklian. Liberal Legislative Council Leader Mike Gallacher took on Police and Emergency Services and Greg Smith became Attorney-General. Brad Hazzard was given Planning and Infrastructure, Pru Goward Family and Community Services and Women, and National Adrian 
Piccoli Education. Three Liberals without previous frontbench experience joined the cabinet. Victor Dominello became Minister for Citizenship, Communities and Aboriginal Affairs and new Assembly Members Robyn Parker (previously an MLC) and Graham Annesley went straight into cabinet as Ministers for Environment and Heritage and Sport and Recreation respectively. National Kevin Humphreys was given the newly-created portfolios of Mental Health, Healthy Lifestyles and Western New South Wales. The Liberal Party's Shelley Hancock became the Legislative Assembly's first female Speaker while Liberal Don Harwin was elected President of the Upper House (Sydney Morning Herald, 4 April 2011; Australian, 4 April, 4 May 2011).

The Coalition had devoted much time to planning for transition to government and major administrative changes were quickly put in place. The thirteen Departmental Clusters created under former Premier Nathan Rees were reduced to nine: Premier and Cabinet, Trade and Investment, Treasury, Finance and Services, Health, Family and Community Services, Attorney-General and Justice, Transport, and Education and Communities. Each cluster was headed by a co-ordinating Minister and Principal Department. The concept behind this reorganisation was to improve performance by separating strategic leadership from service delivery. The most controversial change was the transformation of the Department of Environment, Climate Change and Water into an Office of Environment and Heritage reporting to the Premier. The move was criticised as a downgrading of environmental issues. More positively, the removal of responsibility for heritage from Planning eliminated a potential conflict of interest. The Department of Planning became Planning and Infrastructure and moved into the Premier and Cabinet Cluster. The Premier will also have responsibility for the Public Service Commission, a key Coalition initiative aimed at depoliticising the public sector. A new Cluster of Finance and Services was created, taking the Office of State Revenue and Expenditure Review Directorate from Treasury. The idea was to give the new department responsibility for revenue raising "to leave Treasury free to pursue its principal role of preparing the State budget". Some, however, interpreted the change as an attempt to reduce the influence of Baird. Another major restructure was the centralisation of control over public transport and roads under Transport for New South Wales. The powerful Roads and Traffic Authority and three other agencies were abolished as part of the reorganisation. Sydney Ferries will be run by a private operator with the government retaining control of fares, routes and staff (Australian, 5, 9-10 April 2011, 15 July 2011; Sydney Morning Herald, 4, 5, 20 April 2011).

Changes in personnel were relatively few. The heads of Health (Deborah Picone), Treasury (Michael Schur) and Premier and Cabinet (Brendan O'Reilly) quickly departed. The Director-General of Education, Michael Coutts-Trotter, a long time ALP staffer and husband of Federal Labor Minister Tanya Plibersek, was removed but given a new position as head of Finance and Services. Important new appointments included former Liberal Premier Nick Greiner as chief of Infrastructure NSW, the body charged with planning the state's infrastructure strategy, and former senior Canberra bureaucrat Peter Shergold to head the Public Service Commission. The chief executive of the South Australian Premier's Department, Chris Eccles, was appointed Director-General of the Department of Premier and Cabinet (Sydney Morning Herald, 2, 24, 30 April 2011). Another major appointment, although not as a result of the change in government, was that of Tom Bathurst QC as Chief Justice following the retirement of Jim Spigelman just before the election (Sydney Morning Herald, 14 May 2011).

O'Farrell unveiled a hundred-day action plan soon after being sworn in and set about implementing it with determination. Inquiries were established into the former 
government's sale of electricity assets, planning legislation, regional land use, the controversial Barangaroo development on the harbour foreshore, and the possibility of introducing US-style recall elections. An Expenditure and Management Audit was created to review the state's finances and public sector productivity and service delivery (Sydney Morning Herald, 14 April 2011, 2, 21, 27 May 2011, 17, 21 June 2011; Australian, 9 July 2011). Legislation was passed to: prevent the early prorogation of Parliament before an election except in extraordinary circumstances; give stamp duty relief to seniors selling their homes; extend police powers to move on intoxicated persons in public places; make life sentences compulsory for those convicted of murdering a police officer; implement uniform national occupational health and safety laws (which Keneally had refused to do); ban success fees for lobbyists; set up local area health boards; and establish a payroll tax rebate scheme to create new jobs. The much criticised Part 3A of the Environmental and Planning Assessment Act, which allowed the minister to take control of major development applications from local councils, was repealed. Although local authorities will now have a greater role, applications for private projects of "genuine state significance" will be determined by a reconstituted, more accountable Planning Assessment Commission. The Minister remains the consent authority for state significant infrastructure (New South Wales Parliamentary Debates, 16 June 2011; Sydney Morning Herald, 5 April 2011, 14 May 2011, 17 June 2011).

O'Farrell's most controversial action was capping public sector wage rises at an annual 2.5 per cent. This was the previous government's widely circumvented target. Any increases beyond this will have to be funded by achieved, not just promised as under Labor, increases in productivity. Since 1997, public sector wages have grown "by $21.1 \%$ - about double the growth in the private sector" (Australian, 3 June 2011). The Industrial Relations Commission will be obliged to follow the new guidelines instead of providing a means of avoiding them as was previously the case. A new section in the Industrial Relations Act provides that "when making or varying awards or orders the Commission must give effect to the Government's policy on conditions of employment for the public sector as declared under the regulations" (New South Wales Parliamentary Debates, 24 May 2011). The union movement and Opposition vigorously opposed the legislation; however, it passed the Legislative Council after a three-day filibuster. The government won the support of the Christian Democrats by excluding the police and the Shooters and Fishers by exempting local government employees. In an attempt to make the changes more palatable, O'Farrell applied the same salary restrictions to MPs and senior public servants (Sydney Morning Herald, 25, 26, 31 May, 3, 4, 5, 15 June 2011).

Although the new government's early months generally went smoothly, there were two stumbles. Soon after taking office, O’Farrell claimed to have discovered a $\$ 5.2$ billion "black hole" in the state's finances. He accused the former government, with the complicity of Treasury, of "cooking the books" and sent Treasury Secretary Michael Schur on indefinite leave. A former head of Treasury, Michael Lambert, was asked to conduct an independent audit. His report found that there was no "black hole" and that Treasury had not concealed or misreported information. Although vindicated, Schur resigned and was replaced on an acting basis by Lambert (Australian, 28, 29, 30 April 2011). Another financial worry for the incoming government, this time a real one, was the huge blow-out in the cost of the solar electricity bonus scheme. O'Farrell acted quickly to slash retrospectively the generous tariff paid to householders who installed solar panels from 60 to 40 cents per kilowatt hour. After protests from participants in 
the scheme, the solar industry, his own backbench and Legislative Council crossbenchers, O'Farrell abandoned the proposal in June (Sydney Morning Herald, 19, 20, 24, 25 May 2011, 7, 8 June 2011).

\section{The Opposition}

As had been widely expected, Keneally stepped down as Labor Leader after the election and was replaced on 31 March by John Robertson who had the backing of the ALP machine. The former head of Unions New South Wales, Robertson had been an MLC since 2008 and had transferred to the seat of Blacktown at the election. In his previous role, Robertson had played a key part in the campaign to prevent the Iemma government privatising electricity. Iemma and Paul Keating criticised his appointment on this ground. Others believed Robertson's image as a former union strongman would not go down well with the electorate. The new Opposition Leader commented:

[...] I don't underestimate the work that has to be done [...] I think we have to rebuild trust with everybody in NSW. What we saw was people who voted Labor their whole lives [...] vote Liberal. I'm going to have to rebuild trust with those people (Sydney Morning Herald, 31 March 2011).

Carmel Tebbutt decided not to recontest the Deputy Leader's position and was replaced by another left-winger, Linda Burney (Australian, 7 April 2011). Tony Kelly, who had been elected ALP Leader in the Legislative Council, resigned suddenly on 6 June. Kelly was involved in an Independent Commission Against Corruption inquiry into the purchase by the government on the eve of the election of a property formerly owned by Unions New South Wales. The loss of Kelly, who was personally well-liked and an experienced ex-Minister, was a blow to Labor (Australian, 7 June 2011). Two other MLCs, Eddie Obeid and John Hatzistergos, resigned on 10 and 19 May respectively. The departing members were replaced by Keneally's former Chief of Staff, Walt Secord, barrister Adam Searle, and Steve Whan who had lost Monaro at the election. One of the few capable recent recruits to Labor's parliamentary ranks, Luke Foley, became Upper House Leader.

\section{Victoria January to June 2011 \\ NICK ECONOMOU \\ Monash University}

Victoria began the New Year with a new state government, thanks to the somewhat unexpected outcome to the general election held in November 2010. The last time the Liberal-National coalition won government from Labor was in 1992 under the leadership of Jeff Kennett, and his administration went straight to work with a series of wide-ranging and contentious policies designed to bring about significant economic reform. This new government, however, took a much more incremental and cautious approach in its first six months in office. There appeared to be few really big decisions being made, save for some activity on the matter of "law and order", and here the main driver of the policy debate appeared not to be Premier Ted Baillieu but, rather, his deputy and National party leader, Peter Ryan.

Indeed, Ryan was central to the main events of the first half of 2011, including an eruption of the law-and-order debate that was to eventually see the departure of the 
Chief Commissioner, Simon Overland, and one of the Deputy Commissioners, Sir Ken Jones. This hinted at a crisis within Victoria police command, and this in turn undermined the government's attempt to convey to the public that it was delivering on its election promise of a crack-down on lawlessness with new laws designed to curb anti-social behaviour (including swearing) and a promise to introduce armed guards to patrol Melbourne's suburban railway stations after dark - a policy whose legion of critics forecast has the potential to end in disaster (Age, 15 May 2011). In all of this, Ryan was the public face of the government. The new premier, meanwhile, was either a looming presence somewhere else, or was on leave.

The Labor opposition was confronted with the need to do something about finding a candidate to contest the Broadmeadows by-election necessitated by the departure of former leader John Brumby. While the party organisation wrestled over who should be the candidate (and, in turn, which sub-section of the party's dominant Labor Unity or Right faction would hold sway), the parliamentary Labor team got used to life on the opposition benches. In this, their discomfort was assisted by the new Speaker of the Legislative Assembly, Ken Smith, who won some early infamy for a series of partisan rulings and asides during question time and indicated that he would refuse to allow a staffer in deputy opposition leader Rob Hulls' office to take paid maternity leave (Age, 13 February 2011). The press reported other instances of parliamentary confusion as members got used to their new roles. The most spectacular of these was the failure of senior Liberal ministers to attend divisions - a serious matter given the near equal number of seats held by both the government and the opposition. Womens' Affairs Minister Mary Wooldridge missed a division in May (Age, 27 May 2011) and deputy Liberal leader Louise Asher was apparently asleep in her parliamentary office during a division in June (Weekly Times, 2 June 2011).

\section{Water, Water Everywhere}

Water has been a major point of contention in Victorian politics, and for much of the recent Labor years the problem was an apparent lack of the stuff as a result of a long drought. One of the major policy decisions made in response to this drought was to construct a desalination plant at Wonthaggi in the south Gippsland region. However, the plant's construction then generated its own problems, including cost overruns and a deteriorating industrial situation between unions and the project construction company, Thiess, and these problems became the basis for the Liberal and National parties criticising the project when in opposition. Now that it was in government, the coalition had to re-think its approach to the project, and a departmental review was announced to investigate what ways, if any, the government could extricate itself from the construction and supply contract (Herald Sun, 20 January 2011). The review found that the government had more to lose than gain financially if it were to break with the supply agreements entered into by the previous government. On the basis of this, the Baillieu government announced that the project would continue. This was to be a recurring theme; at the same time that the desalination plant was reviewed, the government also reviewed the "myki" public transport ticketing system that the coalition had criticised when in opposition (Herald Sun, 26 May 2011). Rather like the desalination investigation, the myki review recommended that the system continue to be rolled out (Age, 22 June 2011).

One of the reasons why the plant's construction was experiencing cost over-runs was, somewhat ironically, that Victoria had just experienced one of the coldest and wettest summers on record. South Gippsland had experienced heavy rains and this had caused construction to stop, but the amount of rain that fell on this region was nothing 
compared with the deluges that hit the normally dry and drought-ravaged north central and north-west of Victoria. Three particularly heavy rain events over January and February combined with the massive flooding that occurred in the Murray-Darling basin in Queensland and New South Wales to result in serious flooding of Victoria's Mallee, Wimmera and Goulburn districts. The flooding in the north-west was made worse by the district's topography which meant that flood waters in and around the Murray River took a substantial period of time to recede. The crisis was so bad that it forced Ted Baillieu to abandon one of his periodic leave breaks to meet with stricken farmers and residents, and to promise an inquiry into the performance of the State Emergency Service whose volunteers had struggled to cope with this natural disaster. For the rest of the state, however, the wet summer effectively broke the long drought, and a number of major rural reservoirs such as the Eildon Dam that had been close to drying up were filled to capacity. Victoria's farmers were thus looking forward to a good season, although those farmers in the north-west who were not flooded out had to cope with, first, a locust plague and then a mouse plague.

\section{The National Party Settles Old Scores}

With Ted Baillieu indicating a liking for taking leave whenever possible, deputy premier Peter Ryan was often left in charge and the National party leader was quick to address some matters that had irked his constituency when Labor had been running the place. Duck hunting made a return to Victoria's wetlands, and was marked by a series of violent conflicts between hunters and conservationists in which at least one person got shot (thankfully, not fatally) (Age, 20 March 2011). The Baillieu-Ryan government also decided to allow a return of cattle grazing to the Alpine National Park in the state's east Gippsland region, much to the annoyance of some urban Liberals. Commentators noted that this appeared to be a decision designed to reward the Mountain Cattlemen's Association that had campaigned for the election of the National party in the seat of East Gippsland, held previously by independent Craig Ingram. Critics of the policy argued that the grazing would seriously damage a fragile environment. Proponents of the change of policy, however, claimed that cattle grazing was a fuel reduction measure as part of the new government's approach to bush-fire management. This outraged conservationists, who immediately appealed to the federal Labor government to intervene (Australian, 12 January 2011). Federal environment minister Tony Burke threatened to use Commonwealth powers to have the cattle removed, but the onset of autumn meant that the threat was not carried out as local farmers brought their cattle out of the park ahead of the winter season (Herald Sun, 12 April 2011).

In addition to being the deputy premier, Ryan also holds the important ministerial portfolio of Police and Emergency Services, and in the area of policing a strong sense of retribution towards those associated with the previous government was also discernible. The primary subject of Baillieu-Ryan displeasure was the then Chief Commissioner, Simon Overland, who had been installed with great fanfare by the previous government. In addition to being seen to be so close to the previous government, Overland's leadership of the police was subject to a range of other pressures. The Police Association opposed Overland's maintenance of the previous government's parsimonious approach to police salaries and was also angry about his role in the failed corruption case against former Association secretary Paul Mullett. There were also rural interests angry with Overland for his association with former Chief Commissioner Christine Nixon who was seen as having failed to provide adequate leadership during the Black Saturday bushfire emergency in 2010. Then there 
was the matter of the internecine power struggle going on for control of police command that had resulted in the sudden departure of Deputy Commissioner, Sir Ken Jones (Age, 2 May 2011).

Having been elected on a "law and order" agenda and wishing to get on with the business of passing stronger anti-vagrancy laws but being surrounded instead by warring police factions and a Police Association television advertising campaign in which both Baillieu and Ryan were depicted as clowns, the new government looked in its first few months to be in the midst of a law and order crisis of its own. Something had to give, and in early June the government was finally delivered an opportunity to detach itself from Overland. Just before the 2010 election campaign, Overland had officially announced that statistics compiled by the police had indicated a dramatic decline in violent crime. These statistics were then subject to a critical analysis by the Office of the Ombudsman that found that these figures had been incorrect. While no explicit allegation that police had manipulated the statistics for political reasons was made, the implication was clear enough and Overland's position became untenable.

Overland tendered his resignation within a day of the Ombudsman's report, and the government announced that it would establish an independent statutory authority to collate crime statistics (Age, 14 June 2011). With the Police Association still rampant, the Liberal member for Benambra Bill Tilley threatening to quit the party to sit in the Assembly as an independent as an act of solidarity with his former police colleagues (Herald Sun ,12 June 2011), and a Baillieu adviser accused of having an improper meeting with police command to discuss the Overland case (Age, 14 June 2011), the government was desperately pleased to see Overland go as a circuit-breaker to the rapidly cascading problems arising from policing. Assistant Commissioner for Traffic Ken Lahey was appointed as acting commissioner until a selection process for Overland's replacement could be expedited (Age, 16 June 2011). The debate was then allowed to return to the government's preferred topics of rounding up drunks, swearers and vagrants and passing harsher sentencing laws to demonstrate its "law and order" credentials, especially to appease the readers of Melbourne's crime-obsessed Herald Sun newspaper.

\section{The 2011 Budget}

The new Treasurer in the Baillieu government, Kim Wells, handed down the annual budget in early March. The pre-budget commentary was dominated by two themes: firstly, there were constant references to the Kennett era by pundits who argued that the Baillieu government would repeat history and take a scythe to the public sector (a perception the government was happy to feed with constant references to an alleged $\$ 2$ billion "black hole" in public liabilities left by the previous administration); and, secondly, a report emanating from Canberra that, under a review of federal transfers being undertaken by the Grants Commission in the light of projected infrastructure needs in cyclone-ravaged Queensland, Victoria would be foregoing some $\$ 4.1$ billion in GST revenue over the next five years (Age, 4 May 2011). Wells was also under pressure to deliver on some rather expensive promises made during the election campaign, including the aforementioned armed guard proposal for Melbourne's metropolitan rail system.

Notwithstanding these expectations, the budget proved to be a cautious document that maintained many of the programs of the previous government. The government indicated its intention to keep the maligned "myki" ticket system and complete the "Regional Rail" project that would necessitate major track construction through Footscray as part of its commitment to public transport expenditure. The overall state 
debt was increased as a ratio of GDP from 2.6 per cent to 5.9 per cent in what appeared to be a repudiation of the government's previous rhetoric about the need to rein in Victoria's allegedly burgeoning public sector. The budget promised a major increase in expenditure on health ( $\$ 13$ billion) and a boost to law and order expenditure of $\$ 2.1$ billion, thereby allowing the government to meet its election promises. The government outlined a number of "savings", but this did not include taxpayer support for new home buyers which survives for the time being. The government also promised additional funding for child protection services, thereby returning to another election commitment to address the instability in the Department of Human Services that characterised the last years of the Brumby government. In all, the Treasurer argued that when outgoings were subtracted from incomings, the government would be returning a surplus of $\$ 140$ million and that the long-term objective was to return state debt to 2.6 per cent of state production (Age, 4 May 2011). In all, it was a low-key budget from a low-key treasurer in a low-key government.

\section{The Broadmeadows By-Election}

A by-election for the outer northern metropolitan division of Broadmeadows caused by the resignation of former premier John Brumby in 2010 was held on Saturday 19 February. Broadmeadows is one of Labor's safest seats, so the internecine skirmishing that went on within the Labor party's pre-selection process was arguably the more significant political event than the election itself (all the more so given that the Liberal party decided not to nominate a candidate). Broadmeadows tends to be dominated by Labor's Labor Unity faction, but this group in now divided and the pre-selection process became a very messy affair when the two main sub-groups in the faction came up with different candidates. There is a very big Turkish community within Broadmeadows and this is reflected by a strong Turkish presence in the local Labor branches. A former mayor of Hume City and local Labor member, Burhan Yirgit, gave early indications of his intention to seek Labor endorsement with the approval of the Shop Distributive and Allied Trades (SDA) union. However, the other sub-group in Labor Unity known as the "Short-Con" group (a play on the names of Senator Stephen Conroy and MHR Bill Shorten) came up with the idea of projecting a high profile candidate in to the seat. The candidate they came up with was a Frank McGuire.

Victorians will immediately understand the significance of the McGuire name. Frank McGuire is the brother of Eddie McGuire, a media personality and - more significantly - president of the Collingwood Australian Rules Football Club. Cynics suggested that the Short-Con group had hoped to get Eddie to stand but had ended up with the wrong McGuire. In Frank's defence, however, was the fact that he had worked as a political staffer in the past, but for the Australian Democrats rather than for the ALP. In fact, he was not even a member of the Labor party - a matter that riled the SDA who threatened to take the whole process to the Supreme Court. The Short-Con group got its way, however, by obtaining the support of the Socialist Left (Age, 27 January 2011). Frank McGuire was quickly installed into the party, and then obtained pre-selection. Yirgit did his future political prospects no harm with a dignified withdrawal from the contest, but others in the party pointed out that, not only had McGuire not been a Labor man, he did not even live in the electorate (preferring instead to reside in the affluent south-east bayside suburb of Brighton). What followed was a campaign to talk about how the McGuires might now reside in Brighton and Toorak, but that they came from Broadmeadows. Pundits, meanwhile, looked to see if someone amongst the list of other candidates might cause an upset and there was some 
speculation as to whether the Greens might advance in an area not usually considered to be particularly interested in "new politics".

As it turned out, Labor's new recruit did prevail on primary vote (53.4 per cent), and, after the distribution of preferences, with a two-party vote of 69.8 per cent slightly down on the general election. A little less than 79 per cent of eligible voters attended (down 10 percentage points on the general election), and the informal rate was 9.5 per cent (1.9 percentage points higher than the general election). One of the interesting features of the count was the failure of the Greens to achieve a primary vote higher than 6.1 per cent (down 1.4 percentage points on the general election vote). For reasons best known to itself, the Victorian Electoral Commission reported the two party vote as a Labor-versus-Greens contest, but this was manifestly not the case. The second preferred candidate was Celal Sahin, who had Liberal party connections and who polled a primary vote of 20.2 per cent.

\section{Vice Regal Change}

Not only has the party persuasion of Victoria's parliamentary government changed, so too has there been a change at the Vice Regal level. In late February, Premier Baillieu announced that Alex Chernov SC would be replacing David de Kretser as Victroria's Governor and head of the Executive in Council. Chernov, who is 72, was born in Lithuania and came to Australia as a child when his family fled the advance of the Soviet Union at the end of the Second World War. An alumnus of Melbourne High and the University of Melbourne, Chernov studied law, became a barrister and was later to serve as a justice of the Supreme Court and of the Court of Appeal. He has also served as Chancellor of the University of Melbourne (Age, 4 May 2011).

\section{Conclusion}

The new era of Liberal-National coalition governance in Victoria began in a low-key fashion. In opposition, the coalition had been trenchant critics of many of the things that the previous Labor government had done, particularly with regards to water policy, public transport ticketing and financial management. Yet, in government, the Baillieuled coalition has actually maintained the line set by its predecessor on "myki" and the "desal plant", and even went as far as increasing the state's debt-to-productivity ratio in its first budget. The Liberal leader showed a penchant for taking leave, with the result being that the Deputy Premier, Peter Ryan, appeared to be the real driver of the policy debate. This was particularly so when it came to getting duck hunters back into the state's swamps, cattle back in to the Alpine National Park, and Simon Overland out of the Victoria police force. 
Table 1: The Broadmeadows By-Election Result

\begin{tabular}{|l|l|r|c|}
\hline Candidate & Party & Primary Vote \% & Two Party Vote \% \\
\hline Marr, Graeme & Ind. & 6.0 & \\
Kaliniy, Joseph & Ind. & 1.0 & \\
McGuire, Frank & ALP & 53.4 & 69.8 \\
Schorel-Hlavka, G. & Ind & 0.6 & \\
Hobart, Mark & DLP & 5.6 & \\
Byrne, Peter & Ind. & 2.0 & \multirow{2}{*}{30.2} \\
Sahin, Celal & Ind. & 6.2 & \\
Dawson, Graham & Greens & 5.0 & \\
Davis, Merinda & Sex Party & 9.5 & \\
\hline Informal & & 78.5 & \\
\hline Participation & & & \\
& & & \\
\hline
\end{tabular}

Source: <http://www.vec.vic.gov.au/Results/stateby2011resultBroadmeadowsDistrict.html>

\section{Queensland January to June 2011

\author{
PAUL D. WILLIAMS \\ Griffith University
}

\section{Overview}

The first half of 2011 saw history dramatically made on several fronts. Devastating natural disasters jeopardised the state's economic future, just as the Bligh government's own prospects were threatened by the boldest experiment in recent Queensland political history. The Parliament, too, ventured into new territory, with contentious committee reforms passed, and with a prisoner called to the Bar. Yet another new political party also made its mark.

\section{The Deluge and the Wrath of Yasi}

In the lead-up to the capital's worst flooding in thirty-seven years, Brisbane - along with a third of the state - recorded in 2010 its wettest spring since 1972. By early December, Brisbane's two major dams, Wivenhoe and Somerset, had reached 100 per cent capacity, and would rise higher still (Courier Mail, 1 December 2010). Further rains saw some of the worst regional flooding in 150 years, with thousands of residents along the Condamine, Balonne, Fitzroy, Burnett and Mary rivers fleeing the small towns of Chinchilla, Theodore, Jericho, Alpha, Emerald and Dalby, and from the larger centres of Rockhampton and Mackay. Later flash flooding in mid-January in the Lockyer Valley 100 kilometres west of Brisbane saw the towns of Grantham and Murphy's Creek, as well as the City of Toowoomba, suffer multiple fatalities. It was a tragic backdrop to 13 January when the Brisbane River peaked at 4.46 meters - lower than 1974's 5.5 meters yet sufficient to inundate thousands of homes and businesses. A 
total of thirty-five people lost their lives, with property and infrastructure damage estimated at \$10-30 billion (www.abc.net.au).

If the consequent suspension of coal and other mining failed to inure Queenslanders to a new economic reality, the onslaught of category five tropical cyclone Yasi in early February surely did. Crossing the coast between Innisfail and Cardwell in north Queensland, Yasi left Tully and other localities severely traumatised with the loss of one life and estimated damage of up to $\$ 3$ billion - Australia's costliest cyclone since Darwin's Tracy in 1974. Loss to north Queensland tourism would approximate \$1 billion, and the damage to the banana and sugar industries alone would exceed $\$ 500$ million.

Political rewards emerge from curious quarters, and the natural disasters provided Premier Anna Bligh and her Labor government - after a series of crippling public opinion results since 2009 on the heels of unpopular asset sales (see previous Chronicles) - a dramatic and unparalleled fillip. Bligh won kudos for her grasp of technical and geographic knowledge as she fronted around-the-clock media conferences during which she updated the nation on the state's predicament. Yet it was her "Queensland speech" at the height of the crisis that earned her the most respect. On 13 January, a usually sober and occasionally wooden Bligh dropped her guard and tearfully declared:

As we weep for what we have lost, and as we grieve for family and friends and we confront the challenge that is before us, I want us to remember who we are. We are Queenslanders. We're the people that they breed tough, north of the border. We're the ones that they knock down, and we get up again (www.brisbanetimes.com.au).

Unashamedly parochial, the address nonetheless contrasted favourably with Prime Minister Julia Gillard's more sombre statements. Few were surprised, then, that opinion polls bounced for Bligh, yet even the Labor faithful could not have forecast the magnitude or rapidity of the reversal. According to Newspoll, Labor - at the depth of Labor's despair in December 2010 - attracted only 26 per cent primary vote, or 41 per cent after preferences: a swing of 10 per cent since the 2009 election, and sufficient for the loss of thirty-eight seats, and government. Bligh's personal approval had sunk to 24 per cent, and voter dissatisfaction had soared to 67 points. Bligh, as preferred premier, was rated even lower than the relatively unknown Opposition leader John-Paul Langbroek, 31 to 41 points (www.newspoll.com.au). Yet, just weeks after the floods, Labor had returned to an election-winning position, with the government now enjoying 38 per cent primary vote, or 52 per cent after preferences. Bligh's approval had climbed to 49 per cent, and voter dissatisfaction had fallen to 43 per cent. Bligh was once again preferred premier over Langbroek, 53 to 26 points. It was the largest reversal in Newspoll history.

Bligh's swift appointment of a commission of inquiry undoubtedly added to voters' approval of the Premier's handling of the crisis - one rated as "good" by 93 per cent of Galaxy poll respondents (Courier Mail, 21 February 2011). The inquiry — headed by Justice Cate Holmes and assisted by former Police Commissioner Jim O'Sullivan and hydrologist Phil Cummins - would issue an interim report in August, and a full report in January 2012. Bligh's launch of a Premier's Flood Relief fund also appeared timely, with the fund attracting $\$ 100$ million (with a third donated by the public) by 19 January.

Yet the Premier still suffered her critics. It was alleged at the end of January, for example, that more than $\$ 700,000$ from a disaster fund in the wake of cyclone Larry in 2006 was still undistributed, and, in February, the Premier was strongly rebuked for her 
appearance in a Women's Weekly photographic spread. Bligh took advantage of her renewed mandate, however, and executed a key cabinet reshuffle. Paul Lucas remained Deputy Premier but was sidled out of the sensitive Health portfolio (after the payroll disaster - see previous Chronicles) and into the Attorney-General's chair. Cameron Dick swapped the Attorney-General's office for the higher-profile Education portfolio. It was also alleged that retiring Energy and Water Utilities Minister Stephen Robertson refused the Premier's overtures to return to the backbench (Sunday Mail, 20 February 2011).

\section{Committee Quarrels}

December 2010 saw one of the most contentious committee reports handed down to the Queensland Parliament, with potential reforms the most far-reaching since the abolition of the Legislative Council in 1922 (see previous Chronicle). The bipartisan Review of the Parliamentary Committee System Committee - established in February 2010, and chaired by Judy Spence (Labor, Sunnybank) - made fifty-five recommendations, most of which were well-received. These included the bipartisan appointment of independent officers such as the Ombudsman, and the introduction of a series of portfolio committees ${ }^{1}$ designed to scrutinise policy development in service delivery areas. Other recommendations enjoyed mixed reception. With all bills to be routinely dispatched for up to six months' committee review, there were fears of legislative gridlock. With the portfolio committees' ability to investigate departmental "incidents" such as the Health payroll fiasco (see previous Chronicle), some also suspected politics would play a bigger role than policy. Most were happy, however, with a more scrupulous Budget Estimates process that would now quiz senior public servants.

Yet it was sections 8-13 of the report that stirred most angst, not only from serving Speaker John Mickel but also from former Speakers, Members and Judges who claimed the super-committee would shift further power from the legislature to the executive and, in being "wrong in principle and dangerous in practice", would "make Queensland the laughing stock of the Westminster world" (Courier Mail, 21 December 2010; Australian, 5 April 2011). This six-member Committee of the Legislative Assembly would consist of the Premier, Deputy Premier and Leader of Government Business (or their nominees), and their Opposition counterparts (or their nominees). High on the list of opponents' initial grievances was the Speaker's exclusion from the super-committee's deliberations on Privilege and Standing Orders - the very rules upon which the Speaker would later be required to rule. A compromise was later settled, and the Speaker would soon be included "when the committee is dealing with a matter relating to the standing rules and orders" (www.parliament.qld.gov.au). The super-committee's transfer of the Legislative Assembly's power to administer, and budget for, the parliamentary precinct to the Department of Public Works incurred similar outrage. Yet, for many, the committee's ability to assume sole discretionary power to investigate breaches of Standing Orders and Privilege was the final straw. It

\footnotetext{
${ }^{1}$ The portfolio committees are Community Affairs; Environment, Agriculture, Resources and Energy; Finance and Administration; Health and Disabilities; Transport, Local Government and Infrastructure; Industry, Education, Training and Industrial Relations; and Legal Affairs, Police, Corrective Services and Emergency Services. In addition to the new Committee of the Legislative Assembly super-committee, there is also a new Ethics committee, and the maintenance of the existing Parliamentary Crime and Misconduct Committee. See <http://www.parliament.qld.gov.au/en/workof-committees/committees $>$.
} 
was, critics said, a further distortion of Queensland's already blurred separation of powers.

The debate saw a rare public split in Labor's ranks as those supporting the change, including former minister Rob Schwarten, conflicted with those opposed, including former Speaker Jim Fouras. Inferences were even drawn from the Speaker's failure to secure approval from the Premier's office for one leg of an international trip, despite Mickel already having departed Australia (Courier Mail, 12 March 2011). The contretemps had little effect, however: the Parliament of Queensland (Reform and Modernisation) Amendment Bill was passed by the Legislative Assembly in mid-May, and the supplementary Parliamentary Service and Other Acts Amendment Bill was passed in early August.

\section{The LNP and the "Newman Experiment"}

If casual acceptance of the Committee of the Legislative Assembly suggested the electorate cared little for the separation of powers, its embrace of the Liberal-National Party's bold leadership experiment indicated an even greater disregard for Westminster conventions. For much of 2010, the LNP and its leader John-Paul Langbroek had enjoyed handsome leads over Bligh and Labor. The LNP in December, according to Newspoll, attracted 45 per cent primary vote, or 59 per cent after preferences. By March, the LNP again had floundered on 38 per cent, or just 48 per cent of the twoparty preferred vote (2PP). For LNP powerbrokers, including State President Bruce McIver, Langbroek's allegedly tepid leadership was too great a risk. Rumours then circulated of a plot to install the only LNP identity it deemed capable of toppling Bligh: Campbell Newman, Brisbane Lord Mayor since 2004 and a figure whose profile was similarly enhanced during and after the floods.

Suggestions that Newman move to state politics were hardly new. Yet, after leaked internal LNP polling indicated the conservatives falling short of victory under Langbroek - but winning in a landslide, 66 per cent to 34 per cent, under Newman moves to install the Lord Mayor gained momentum, and even more so when Newman failed to issue his usual denials (Sunday Mail, 20 March 2011). Langbroek, meeting with Prince William in far north Queensland, said he would "stare down" any incursion. Yet, within two hours of Newman's media conference on 22 March at which he confirmed his bid for the leadership via his nomination for the seat of Ashgrove in Brisbane's inner north-west, Langbroek and deputy leader Lawrence Springborg had convened their own media conference at which both resigned their positions, and refused to accept any new place in Newman's shadow cabinet. Struggling to hide his displeasure, Langbroek added only that politics is a "treacherous business" (Warwick Daily News, 22 March, 2011). Later that evening, the LNP party room elected former Nationals leader and now Newman ally Jeff Seeney (Callide) as "interim leader" defeating Fiona Simpson (Maroochydore) in a secret ballot — with Tim Nicholls (Clayfield) his deputy.

Yet Newman's quest was not all plain sailing. After rumblings from a dumped LNP candidate, Newman was finally endorsed for Ashgrove on 4 April, but not before Labor referred LNP President McIver to the Crime and Misconduct Commission (CMC) over allegations that McIver had urged Moggill MP Bruce Flegg to vacate his seat to make way for Newman (Brisbane Times, 29 March 2011). The CMC exonerated McIver in July. About the same time, Newman and Seeney squabbled publicly when the latter declared he would automatically serve as deputy premier; Newman insisted the deputy's position would be filled only by party room ballot after the election (Australian, 31 March 2011). Newman also attracted fire when he 
implored Queenslanders to donate five dollars to his "can do" campaign, and for resigning as Lord Mayor just days within the statutory twelve-month period that marked the cut-off for a mayoral by-election. Deputy Lord Mayor Graham Quirk (Macgregor ward) was appointed the City's sixteenth Lord Mayor on 7 April 2011.

After fevered negotiations, Newman quickly stamped his brand on the new LNP frontbench. As expected, Springborg refused a portfolio but, contrary to earlier statements, Langbroek accepted Police, Corrective Services and Emergency Services. Howard Hobbs, Ray Hopper, Ray Stevens, Glen Elmes and Peter Dowling were also removed. In their place, Ros Bates, Steve Dickson, Andrew Powell and Mark Robinson were promoted, with David Gibson (Gympie) — dismissed by Langbroek in 2010 reinstated. It was speculated that, given three MPs from each of the Liberal and Nationals tribes were sacrificed, tensions between the two wings still existed (Courier Mail, 12 April 2011).

As above, the issue of official titles proved problematic for the LNP. While "interim leader" Seeney would face Bligh in the chamber, he would eschew the title of "Opposition leader". Newman would instead boast the "LNP leader" and "alternative premier" mantles - each an abrogation of Westminster conventions with which Labor attempted, unsuccessfully, to inflame voter concern. With Newman now "leading" his party from outside parliament it was, after all, a move unprecedented in Australian politics (but not unknown in Canada). Yet when Labor raised the inevitable question of who would be premier should the LNP win a majority yet Newman failed in Ashgrove, LNP powerbrokers (and voters) were dismissive. But a Newman victory remained far from certain, and many questioned the logic in contesting a Labor seat held by a 7.1 per cent margin by popular Environment Minister Kate Jones. Internal LNP polling leaked in late May, however, appeared to confirm Newman was on track to win the seat, with the former Lord Mayor registering a 19 per cent primary swing, or 53 per cent 2PP to Labor's 47 per cent (AAP, 1 June 2011).

In late June, Jones resigned from Cabinet to focus on campaigning, taking the fight up to Newman - who, Labor reminded voters, did not reside locally — "door to door, street to street". A July Newspoll confirmed Newman's lead in the seat, with 50 per cent primary vote (or 55 per cent $2 \mathrm{PP}$ ) to Jones's 37 per cent (45 per cent 2PP). The poll also underscored the propensity for party image and leader performance to overshadow that of local MPs. Seventy per cent of respondents approved of Jones's representation, and only 17 per cent were dissatisfied. Moreover, 47 per cent cited Jones as a "better" MP to Newman's 45 per cent (newspoll.com.au).

The race for Ashgrove drew more attention in June when Bob Irwin, father of the late wildlife handler Steve Irwin, declared his possible nomination for the Queensland Party. Only in September did Irwin decide against standing. Despite the tumult, it appeared the Newman experiment had proved hugely successful: by May, Newman had steered the LNP to 51 percent primary vote to Labor's 31 per cent, or 60 per cent to Labor's 40 per cent after preferences. Interestingly, while Bligh trailed Newman as preferred premier, 49 to 35 per cent, Bligh maintained a satisfaction rating of 40 per cent - 16 points higher than her 2010 nadir. Labor's poor party image rather than Bligh's personal leadership therefore appeared to be the principal determinant of the swing.

\section{Economy and Budget}

The floods and cyclone Yasi exacted an enormous economic as well as human toll. While losses in mining exports contracted the Australian economy by 1.2 per cent in the March quarter, the disasters also raised Queensland's unemployment to 5.6 per cent 
( 0.6 per cent above the national average). The soaring costs of fresh fruit and vegetables also fuelled inflation. Alongside a retarded housing industry, Queensland rated fifth in economic growth in the March quarter among Australia's states and territories (Courier Mail, 8, 18 April 2011). Around the same time, 64 per cent of Queenslanders cited cost-of-living as the state's most pressing issue, with only 24 per cent believing Queensland to be headed in the "right direction". Seventy-nine per cent also opposed the previously announced carbon tax (Sunday Mail, 5 June 2011).

Against this dire backdrop, Treasurer Andrew Fraser delivered on 14 June a gloomy state budget. Where the Mid-Year Economic Review had earlier forecast 1.25 per cent growth, new estimates put the state's growth at zero. Natural disasters had stripped $\$ 6$ billion from mining, $\$ 1.4$ billion from agriculture and $\$ 400$ million from tourism. The state's budget bottom line in $2010-11$ plunged $\$ 2.13$ billion into deficit, with a $\$ 4.06$ billion deficit forecast for 2011-12. The budget will not return to surplus until 2015-16 (Courier Mail, 13 June 2011). Not all news was bad, however, and Fraser forecast the creation of 140,000 jobs over two years. Should 26,000 jobs be created by the next election, the Premier will have met her 2009 pledge to create 100,000 jobs in the life of the current parliament. Fraser also predicted five per cent growth in 2011-12, bolstered by an expected 27 per cent growth in business investment, a $\$ 14.9$ billion capital works program, and $\$ 104$ million training and assistance package (Courier Mail, 12 June 2011). While the 2010-11 state debt measured $\$ 52.8$ billion - $\$ 17.5$ billion lower, Fraser argued, because of the contentious asset sales - debt would soar to $\$ 84.9$ billion in 2014-15 (Courier Mail, 13 June 2011). The Treasurer also announced increased electricity and water rebates for pensioners, $\$ 83$ million for tourism, $\$ 100$ million to reinvigorate the "Smart State" program (fallen into disuse under Bligh), and a Business Commissioner to cut "red tape". While the budget also abolished the compulsory Ambulance Levy (first applied to electricity accounts in 2003), \$600 million was earmarked for the transition of Year Seven into secondary schooling in 2015 (Courier Mail, 14 June 2011). In the LNP's Budget Reply, Shadow Treasurer Tim Nicholls pledged a twelve-month freeze on electricity prices, a three-year freeze on car registration, and a reduction of water bills by $\$ 80$ annually (Courier Mail, 17 June 2011).

\section{Bob Katter}

In May, federal Independent MP Bob Katter (Kennedy) talked up the alleged failure of independents in the current political milieu and mooted a new conservative force in Australian politics. In early June, Katter announced the launch of his Australian Party, warning the major players; "We're coming after you". When, in August, Katter's new outfit merged with the Queensland Party (headed by Beaudesert MP Aidan McLindon), Katter further warned of "blood on the carpet". Federal registration was temporarily held over, however, when objection to the new party's abbreviated name was lodged with the Australian Electoral Commission. When the abbreviation was amended to Katter's Australian Party, or KAP, registration was approved at federal, and later state, level. Katter then campaigned for, among other things, the end of the Australian supermarket duopoly, and the right to "hunt, shoot, fish [and] boil a billy" (Australian, 6 June 2011). While the Queensland Party faced deregistration due to McLindon's departure, the party's shell appeared to remain active and, critically, at odds with McLindon. The new KAP received a fillip, however, when a Galaxy opinion poll found 23 per cent of respondents likely to support the new outfit at the next state election (Courier Mail, 6 September 2011). Given that LNP State MP Howard Hobbs 
(Warrego) had, in April, declared Jeff Seeney the "most hated man in the bush", a One Nation-type electoral backlash appeared eminently possible.

\title{
Gordon Nuttall
}

History was made on 12 May when former minister Gordon Nuttall ${ }^{2}$ - by then serving a 12 year prison term for receiving more than $\$ 500,000$ in secret commissions from business figures (see previous Chronicles) - was called to the Bar of Parliament to answer the Legislative Assembly's forty-one charges of failing to declare the payments in the Pecuniary Interests Register. Media commentary speculated that Nuttall, allegedly encouraged by Independent MP Rob Messenger (Burnett) who had visited Nuttall in prison, would "tip the bucket" on a host of sitting MPs. Speaker Mickel, however, set tight parameters for Nuttall and forbade the former minister from straying from his defence. Nuttall, appearing gaunt in an ill-fitting suit, spoke for thirty-six minutes (nine minutes fewer than allocated) in an address broadcast live on commercial television. Nuttall defended the payments as "loans", then attacked the Crime and Misconduct Commission, an assault Mickel was forced several times to cut short. Nuttall's pleas fell on deaf ears and, "on the voices", the Parliament voted to fine Nuttall $\$ 82,000$, an amount the former minister said he could not pay. It marked a sober day for the Queensland Parliament.

\section{Western Australia \\ January to July 2011}

\author{
HARRY C.J. PHILLIPS \\ Parliamentary Fellow, Western Australian Parliament; Honorary Professor, Edith \\ Cowan University; Adjunct Professor Curtin University of Technology
}

\section{LIZ KERR}

\section{Clerk Assistant, Legislative Assembly, Parliament of Western Australia}

Throughout the first half of 2011, federal-state relations remained a central feature of the Western Australian political scene. Tensions were high in a "war of words" between Prime Minister Julia Gillard and Premier Colin Barnett. Disagreements were voiced about the distribution of the goods and services tax (GST) revenue, an increase in state royalty rates, the carbon tax, the question of infrastructure funding and negotiations over the mooted Health Agreement. Although the state budget gave welcome focus to sustainable funding and contracting within the not-for-profit sector, the continued rise in household utility costs and a forecast increase in debt levels drew strong Opposition criticism. The Opposition was itself the centre of media attention early in the year when Ben Wyatt, the youthful Shadow Treasurer, failed in a challenge

\footnotetext{
${ }^{2}$ Nuttall became only the third person to appear before the Bar of the Queensland Parliament, and remains the first prisoner. The others were Justice Angelo Vasta in 1989 and Lands Administration Commissioner Vivian Creighton in 1956. As a "stranger" in the House, Nuttall could not be questioned by MPs. Nuttall was originally sentenced to seven years' jail in 2009, a term extended to twelve years in 2010 after being found guilty of further corruption and perjury charges. On appeal from Attorney-General Paul Lucas, Nuttall's sentence was again increased to fourteen years in June 2011. Nuttall would now be eligible for parole in 2015.
} 
for the Labor leadership. By June, Labor's state poll readings remained poor with the increasing unpopularity of the federal Labor government contributing to the low rating.

\section{Budget Matters}

In presenting his first budget, Treasurer Christian Porter spoke of the "rapid and massive decline in Western Australia's share of GST grants" (Budget Speech, 19 May 2011). Porter forecast that in 2014-15, the final year of the forward estimates, Western Australia would receive only 33 per cent, or one-third of the state's population share. In fact, in February (the month of the Perth bushfires) Western Australia received a $\$ 400$ million GST "windfall" when the share temporarily rose to 72 cents in the dollar from its current record low of 68 cents. Premier Barnett expressed commitment to the Commonwealth Grants Commission principle of horizontal equalisation but believed 75 cents in the dollar should be the "bottom-line". Barnett hoped the GST review, commissioned by federal Treasurer Wayne Swan and due for release in 2012, would address Western Australia's concerns.

The state budget was underpinned by a $\$ 442$ million surplus and predicted steady growth of 4.5 per cent per annum. The government signalled an increase in the royalty rate for iron ore fines (a production by-product) staggered over 2012-2013 to 7.5 per cent, in line with the rate applying to "lump" ore. This change reflected the fact that iron ore "fines" account for the majority of the state's iron ore shipments and are no longer considered an inferior product in the global market. However, the action drew vehement criticism from the federal Treasurer because the proposed mineral resource rent tax (MRRT) deal was to rebate mining companies for the payment of state royalties. According to Prime Minister Gillard, Western Australia had scored an "own goal" as the increase in its royalties revenues would result in a declining share of GST funds, and the loss of infrastructure funds associated with the MRRT. Treasurer Christian Porter illustrated the irony in the fact that "unproductive revenue raised from pokie machines [in other States and Territories] is excluded from this penalisation process [...]"(Legislative Assembly, Parliamentary Debates, p.3572, 19 May 2011).

Premier Barnett sought to feature the sustainable funding and contracting of charities and the not-for-profit sector with a $\$ 604$ million allocation, but publicity was soon directed to the rise in household costs. Residential customers faced increased electricity tariffs of 5 per cent (between 9 and 30 per cent for medium and large businesses) and water prices were increased by 8.5 per cent. Opposition Leader Eric Ripper claimed the government's decisions on fees and charges raised the average family's bills from $\$ 4,820$ to $\$ 5,893$ in three years (West Australian, 25 May 2011). Another criticism levelled by Ripper, but defended by Porter as within Triple A specifications, was the looming state debt, set to reach \$22.4 billion by June 2015 . Ripper also highlighted the government's abandoned election promises, including the Royal Perth Hospital Development, the Ellenbrook rail extension and the Bunbury to Albany gas pipeline.

There was no substantial budget provision for the widely debated new sporting stadium, although in January the Premier aired a proposal to build a stadium at the Belmont Park racetrack which was later discarded. In late June, despite strong representation by the Subiaco City Council, a site at Burswood near the State Tennis Centre was nominated for a 60,000 seat stadium (with capacity to be increased to $70,000)$ expected to be completed in 2018. An indicative cost of $\$ 700$ million was likely to increase, particularly with the anticipated infrastructure and transport costs associated with the project (West Australian, 29 June 2011). 


\section{Parliament and Parties}

Labor continued to suffer from poor opinion poll ratings at both the state and federal tiers of politics. According to Newspoll (Australian, 24 June 2011) the state Labor primary vote was as low as 30 per cent with a two-party preference reading at 43 per cent for Labor and 57 per cent for the Liberals and Nationals. Colin Barnett was regarded as the better premier by 58 per cent of respondents with 18 per cent in favour of Eric Ripper. Given this electoral climate, veteran Labor MLA Tom Stephens sought support (in a leaked email) to bring a leadership spill motion to caucus on 10 February 2011, which sparked a messy leadership challenge by Ben Wyatt, the youthful Shadow Treasurer. Ripper reacted uncharacteristically with an assertion that Stephens was "incompetent and ineffective", which Stephens responded was indicative of Ripper's lack of leadership qualities. Much was made of the spectre of trade union influence given that Ben Wyatt had not been able to gain the endorsement of the "left" nor "right" unions. The trade union leaders, Dave Kelly and Joe Bullock, denied the extent of their influence, and in reality Wyatt could not garner sufficient party room support. The action temporarily dented Wyatt's credibility but Ripper, while stripping him of the shadow Treasury portfolio, offered him Education where he soon made an impression. A shuffle of the shadow portfolios followed a realignment of published faction groupings (West Australian, 7 January 2011). Michelle Roberts, still influential in the party, became shadow Treasurer while MLC Ken Travers added finance to his transport brief, following Premier Barnett's earlier split of Treasury and Finance. Paul Papalia, who had backed Stephens' leadership criticisms, lost Corrective Services but retained Local Government. The latter portfolio continued to be troublesome for the government, which attempted to uphold its policy of seeking the amalgamation of local authorities. In late June the Western Australian Labor State Conference joined the Labor parties in Queensland, South Australia and Tasmania in supporting same-sex marriage. Although largely symbolic, as only Canberra has the power to amend the Marriage Act 1961, the motion kept the issue in the public mind.

One troublesome matter for Nationals' Leader and Regional Affairs Minister Brendon Grylls was the demand by the Information Commissioner, Sven Bluemmel, to release a trail of correspondence between himself and mining magnate Clive Palmer's company Mineralogy (a significant donor to the Nationals and Liberals). Labor's Mark McGowan raised the matter in parliament late in 2010 and had obtained documents showing Mineralogy had a \$45 million Environmental Protection Agency bond dropped from a Pilbara Iron Ore Project. Despite Grylls' reluctance to release the document, the issue faded as the eventual release revealed no direct approach by Palmer to Grylls, nor any promises from the minister (Weekend West, 19-20 January 2011). Premier Barnett had strongly supported Grylls' stance and also backed Troy Buswell in May when the Transport Minister made a decision to block a proposal from mining company Cazaly Resources to ship iron ore through the port of Fremantle. Opposition Leader Eric Ripper expressed reservations because the personal relationship between Buswell and Fremantle Independent Green Adele Carles gave the appearance of a conflict of interest. The Opposition could not however establish that due process had not been followed, although a newspaper editorial suggested approaches from Carles to Buswell as minister, "be formalised in writing to ensure a clear record of official dealings and remove any suspicion of favourable treatment for political advantage" (West Australian, 19 May 2011).

Nationals Minister Terry Redmond (Agriculture and Food) travelled to Indonesia in mid-June to address the issue of live cattle exports, which were suspended in the light 
of an $\mathrm{ABC}$ Four Corners exposé into animal cruelty in the industry. Redmond's approach was to do whatever was needed to get the market in Indonesia up and going but it was really a matter of federal jurisdiction. It was soon obvious, however, that the dislocation to the industry was to be severe in both the short and long run. Another economic setback in late June threatened Premier Barnett's "personal dream" of a deep water port at Oakajee in the state's mid-west. An announcement by Sinosteel to shelve its Weld Range iron ore mine meant the port would be denied about a third of its planned throughput (West Australian, 24 June 2011). Meanwhile Woodside's plan to develop a gas hub sixty kilometres north of Broome continued to fuel protests. The $\$ 30$ billion project to pipe gas from the Browse Basin to James Price Point still required approval from Canberra and a final investment decision.

On 24 February in parliament, the Premier announced a proposal to consolidate ministerial offices and central government departments within the parliamentary precinct over the coming years. Included in this plan was the decision to relocate the office of the Premier and the Cabinet room to Hale House, a heritage-listed building close to the parliament. The cost of restoration would be significant given its heritage status and in May, Labor frontbencher, Mark McGowan, questioned the costings of what he dubbed the Premiers' Palace, citing a document that suggested UnderTreasurer Tim Marney had given advice that the offices could be accommodated at a reduced cost in the government-owned Dumas House (West Australian, 26 May 2011).

The colourful Labor MLA and "frontbencher" John Quigley raised eyebrows on 25 May 2011 when he claimed under parliamentary privilege that his family were suffering "an extortion nightmare". Quigley alleged that David Everett, a former SAS soldier, convicted criminal and husband of Quigley's former partner and one-time Acting Information Commissioner Darryl Wookey, had sent anonymous threats which were received by Quigley's wife. Members were told of the history of events, although Quigley heeded the Speaker's advice and did not read the full contents of a letter for fear of affecting a civil defamation case between himself and Wookey that was set down for trial in the Supreme Court. On 16 June the Procedure and Privileges Committee tabled a Report on a Person Adversely Referred to in the Legislative Assembly which contained a chapter and verse refutation of Quigley's claims. Meanwhile, parliament delivered a number of condolence motions that included former football great Stan "Popsy" Heal (February), Subiaco Liberal stalwart Tom Dadour (April), former Labor Minister John D'Orazio (April) and Ian Metcalf, a former Attorney-General in Sir Charles Court's government (May). Unrelated to parliament, Sir Ernest Lee-Steere, the former Lord Mayor of Perth, prominent businessman and long-time Chairman of the Western Australian Turf Club, died in early January at the age of ninety-eight.

\section{Law and Order}

For the period January to June 2011 Law and Order continued to flavour much political debate, with the actions of the Corruption and Crime Commission once again in the spotlight. Former minister Norm Marlborough had his conviction for lying to the CCC overturned by the Court of Appeal, while the CCC was criticised over its actions in relation to a witness who committed suicide one day before scheduled public hearings in which he would feature. In a report tabled by the parliamentary oversight committee it emerged that CCC operatives had become aware that the witness had been searching suicide-related websites and had attempted to purchase a scalpel in the weeks leading to his death, yet the agency continued with its intention to hold public hearings. The positions of Commissioner and Acting Commissioners for the CCC remained vacant 
for the six-month period, with the Attorney-General reportedly casting a wider net in an effort to attract suitable candidates. Commissioner Len Roberts-Smith retired at the end of 2010, just as the debate on whether the CCC should focus more on organised crime arose. The Premier had indicated a preference for the shift in focus, whilst opponents (including Roberts-Smith) feared the move would be at the expense of smaller yet important misconduct work. The parliamentary oversight committee recommended against the move, a position confirmed by Governor designate Malcolm McCusker, making his final appearance before the committee as the former and inaugural parliamentary inspector for the CCC. McCusker suggested instead that the Public Sector Commission should be given increased powers to "eavesdrop" on phone conversations, with the aim of then questioning suspects in a private setting.

In June the government introduced a ban on the sale of the synthetic cannabis known as Kronic, using the Poisons Act 1964 as the vehicle to do so. Kronic had reportedly become popular with mine-site and other workers subject to drug testing as it did not register through standard drug testing measures. At the time Kronic was banned, a survey had indicated that Western Australians may have become more tolerant of cannabis usage, which appeared contrary to media coverage (West Australian, 1 August 2011). In 2003 the Labor government had decriminalised cannabis use through an infringement system for possession of up to 30 grams and by allowing a person to grow up to two plants for personal use. In October 2010 the government's Cannabis Reform Bill gained Royal Assent, with more stringent laws due to come into effect in August 2011.

As signaled, Attorney-General Christian Porter moved to amend the Juries Act 1957 to restrict the range of exemptions for jury service. In early June the Attorney-General announced an ex gratia payment to former inmate Darryl Beamish of $\$ 425,000$ (said by supporters to be too low), expressing "the State's sincere regret" for his wrongful conviction. Beamish had served fifteen years in jail for the 1959 murder of Jillian Brewer in Cottesloe (West Australian, 3 June, 2011). Toward the end of June the government released its Prostitution Green Bill for public comment. It immediately faced criticism over plans for a central register and licensing system for prostitutes and brothel owners, with concern this would simply drive the industry further underground, create a rise in "home visit" escorts and increase the use of the casino as a meeting point for clientele.

The announcement in 2010 that Perth would be the host state for the 2011 Commonwealth Heads of Government Meeting (CHOGM) sparked plans for a $\$ 9$ million redevelopment makeover for the city's iconic Kings Park, in particular the government-owned Fraser's Restaurant complex and surrounding areas. CHOGM was expected to provide a significant economic benefit to the state, with the government budgeting around $\$ 30$ million to stage the event. Legislation was introduced in February to give police and the CCC special powers with respect to CHOGM (including stop and search powers of the kind rejected by the parliament in 2010), with the bill completing a sometimes tortuous journey through the Houses toward the end of June. Police Minister Rob Johnson took carriage of the bill in the Assembly and faced tougher than expected scrutiny led by Opposition Police spokesperson Margaret Quirk, who examined the bill clause by clause. Quirk's main concern was that any laws introduced for CHOGM needed to provide the right level of security for delegates and foreign dignitaries while minimising disruption to the public. 


\section{Education and Health}

Budget outlays for education increased by 4.9 per cent and health by 8.2 per cent. After much controversy the government expanded the School Air Conditioning Policy to include all public schools in the state. Still at issue was whether was the State High School system, with the move to the national curriculum, had the capacity to accommodate Year 7s which had been the direction of most private schools. Newly appointed Shadow Education Minister Ben Wyatt landed a few blows in June when he uncovered the existence of two drafts of a report as to whether funding would be phased out for the Carson Street independent school, which catered for disabled children. On 23 June Education Minister Liz Constable, who had earlier signalled her intention to retire at the next election, made it clear that the school's funding would continue. Meanwhile, the Premier ordered a Public Sector Commission inquiry into how and why the school was given a copy of the report which favoured continued funding, while the Opposition's version obtained by Ben Wyatt, recommended phasing out the $\$ 200,000$ per annum allocation.

Health negotiations continued in an attempt to seal a state-federal agreement and prospects improved after the Gillard government agreed to drop its GST clawback. Meanwhile a review of the Tobacco Products Control Act 2006, which governs the state health promotion body known as Healthway, was creating controversy. One discussion paper called for an end to the requirement that 30 per cent of its funding go to sports, while the Western Australian Sport's Federation (WASF) focussed on the effectiveness of the co-sponsorship policy and the ways to improve the agency's relationship with the sporting bodies. According to WASF, banning alcohol, fast food, soft drink and confectionary companies from sponsoring sport would cost more than $\$ 20$ million a year in lost revenue (West Australian, 13 June 2011). Chairwoman of Healthway, Rosanna Capolingua, suggested that the vast majority of sports agree with Healthway's policy of investing tax dollars to help them move away from alcohol and junk food (West Australian, 23 June 2011). Prominent in the debate was Professor Mike Daube, Director of the McCusker Centre for Action on Alcohol and Youth at Curtin University (Weekend West, 21-22 May, 2001), and the Assembly's Education and Health Standing Committee which tabled a series of reports related to its Inquiry into the Adequacy and Appropriateness of Prevention and Treatment Services for Alcohol and Illicit Drug Problems in Western Australia throughout the period under review.

\section{The Arts and the Governorship}

On 28 January 2011 the new State Theatre Centre in the Northbridge Cultural Precinct was opened with fanfare rivalling His Majesty's Theatre opening in 1904 and the Perth Concert Hall in 1973. The precinct featured a new 575-seat theatre named after the late Heath Ledger, whose father Kim was reported as saying he thought it was "magnificent", imagining that his son had been "a bird on the shoulder of the architect". The Centre was opened by retiring Governor Ken Michael and Premier Colin Barnett. Soon after in March, the Premier announced that prominent Perth barrister and philanthropist, Malcolm McCusker QC, would, from 1 July, become the state's thirty-first Governor. McCusker pledged to further the causes of charity and the Indigenous population, with his $\$ 422,678$ salary to be donated to various charities. Present at Governor McCusker's investiture was Corporal Ben Roberts-Smith, who in late January had received the Victoria Cross, Australia's highest military honour, for 
gallantry in action in hazardous circumstances as a patrol sniper whilst deployed in Afghanistan from May to September 2006.

\title{
South Australia
}

January to June 2011

\author{
HAYDON MANNING \\ Politics and Public Policy, Flinders University
}

The March New South Wales election result, which also saw Labor's worst poll results in fifteen years, sent shivers through the government and fuelled speculation that Rann's tenure may end before his tenth anniversary as premier. A ministerial reshuffle early in the period under review attempted to put a new face on the government. Kevin Foley relinquished Treasury and the deputy leadership; these were taken up by the Right faction's Jack Snelling and John Rau, respectively. Rau had languished on the backbench during the first two terms and would now be thrust into the limelight as the dominant Right faction's preferred candidate to succeed Rann. Indeed, this quickly became evident, with the Premier taking a less prominent role as the government's spokesperson. Rau failed to make much impact, as a series of opinion polls published in The Advertiser and Sunday Mail testified. His main rival, the Left faction's Jay Weatherill, ranked consistently higher than Rau or Rann on the question of who would make a "better Premier". This laid the seeds for rumblings within the Left and the media picked up on hints that the Rann era's days were numbered. As the review period drew to a close, the matter remained unresolved but this situation was unlikely to last. Not unrelated to these matters was a scandal that undermined the moral authority of the Right. A minister's home and parliamentary offices were raided by police and charges laid with regard to accessing child pornography on the internet. None of these matters helped the government position in the polls, which saw it slump to less than 30 per cent for its first-preference support. The Opposition seemed to be in "cruise control" and this drew criticism from the local media.

\section{An Arrest, a Minister Resigns and the Catholic Right's Hold on Cabinet}

The ramifications for the Rann government of a minister's arrest and subsequent resignation remain, at this juncture, unclear. The Advertiser (21 April 2011) announced the news on its front page, "MP Arrest — Police question politician over child images", and reported the seizure of laptop computers. The arrestee's name remained unknown because the South Australian Evidence Act requires that persons accused of a sexual offence must first be committed for trial. As a consequence, reporting relating to the individual's identity was appropriately vague, but something of a lead was provided when the police raided an office occupied by a member of the Legislative Council. The following day the government's leader in the Upper House, Bernard Finnigan, resigned his portfolios without explanation. An unassuming and quietly spoken character, Finnigan typifies the union leader promoted by the factional "machine" to an Upper House seat. He is the political protégé of long-serving Right-wing factional leader, Senator Don Farrell, a powerbroker often referred to as "The Don", due to his capacity to make, and break, political ambitions. When Farrell led the shop assistants' union he appointed Finnigan as his deputy and, subsequently, paved the way for Finnigan's 
entry into the Legislative Council, in May 2006. Both are devout Catholics, a fact that, in relation to Finnigan's resignation, not unsurprisingly drew comment in the media. For example, attention was drawn to remarks he made during his maiden speech that "I am a servant of Christ and subject to His reign in history" (Advertiser, 22 April 2011). He cut a lonely figure when he returned from leave to sit in Parliament and currently awaits deliberations from the court on whether he has a case to answer (The Advertiser, 4, 7 May 2011).

As reported in the previous chronicle, Treasurer Foley's capacity to command his post was diminishing, making a cabinet reshuffle inevitable. As noted above, Foley has passed the baton to younger members of his faction and while undoubtedly disappointed with the way matters had transpired, he could, at least, reflect on supportive commentary, courtesy of an editorial, published in The Australian (8 February 2011). It maintained that South Australian "Labor's success in government [...] is due in no small part to Mr Foley's tenacity [in] [...] winning and maintaining the Triple-A credit rating for the state". Rau remained Attorney-General, but his elevation to the deputy leadership pits him against the Left's Jay Weatherill in an emerging contest over who is most likely to succeed Rann when he either resigns, or is challenged (Sunday Mail, 6 February 2011). As noted above, Rau is favoured by the dominant faction but the opinion polls point to Weatherill enjoying much greater support to succeed Rann. However, "the numbers" appear stacked against him with the conservative Catholic members of the Right deeply opposed to his progressive policy stance and unforgiving of his challenge to Foley one day after the last election. The Right faction was the main beneficiary of the reshuffle, which saw the promotion of staunch Catholics Jack Snelling, Tom Kenyan and Bernard Finnigan. Their rise to cabinet prompted some to wryly comment that the ghost of the Democratic Labor Party had assumed the power it dreamt of a generation ago (Advertiser, 12 February 2011). Accordingly, on social policy the current Rann cabinet is clearly to the right of Redmond's shadow cabinet and something over which Rann has little control, given the sway of Senator Farrell's faction. One consequence of Finnigan's resignation may well be an undermining of Farrell's moral authority and, possibly, faction unity in relation to opposition to Weatherill's ambitions for the leadership.

\section{The Budget and the State of the State's Economy}

A study by the conservative think tank, The Centre for Independent Studies, weighed up the relative fiscal management position of the states over the period 2006 to 2010 across a range of measures, such as gross debt net of financial assets; general government expenses per capita; state public sector employees per 1,000 of population; and average annual growth of real per capita expenses (Robert Carling, "Tax, Borrow, Spend: How States Compare", Issue Analysis, no. 124, 17 February 2011). Its findings made The Advertiser's front page (17 February 2011) with the headline, "State's finances worst in the nation". The research indicated that current per capita expenditure on services to the public is $\$ 9,329$ higher than any other state. This figure, along with a number of other revealing features, underscored the logic underpinning Snelling's first budget, namely, the necessity to curb growth in public sector costs, reduce state taxes and charges and begin to tackle the underfunding of public sector superannuation liabilities. As the report's author, Robert Carling, explained, South Australia was a clear outlier, being well above national average on "general government expenses per capita", with the highest score for "average annual growth in the number of state public sector employees per capita". These findings were known to Foley as he prepared to cut the public sector in 2010, and they now inform Snelling's deliberations. But with 
Labor's traditional heartland within the union movement in uproar, his task of rebuilding faith would not be easy.

It quickly became evident that Snelling would adopt a more consultative approach with the unions and be guided by three key priorities. Firstly, he stated an intention to use "whatever new money in the budget" to protect the "most vulnerable", explaining that this is "what inspired me to join the Labor Party 21 years ago". Secondly, the "massive infrastructure investment that will transform our state and renew its capital as a modern and vibrant polis" would not be compromised and, finally, that the views of the credit rating agencies would be respected in order to keep the Triple-A rating intact (Parliamentary Debates, House of Assembly, 9 June 2011, p. 4133-44). The last point was salient, with Snelling keen to sing the familiar pre-budget refrain warning of an imminent cut to the state's credit rating unless government expenditures and debt were held in check, while forecasting a return to budget surplus sooner rather than later.

Snelling's budget was framed in the context of the 2010 election expenditure promises, which involved significant transport upgrades, the Adelaide Oval upgrade and a new hospital, all against a background of a decline in Commonwealth GST revenue. This sobering reality was also weighed against the rating agencies' preparedness to reward Labor with another Triple-A assessment. Notwithstanding the rhetoric around the need to "be tough", Snelling's budget was a rather modest affair. It entailed minor expenditure cuts and little by way of new revenue initiatives, except for the proposal to lease the government-owned Lotteries Agency. The most significant saving was the proposal to cut 400 public sector jobs, projected to save $\$ 62$ million over two years, and the halving of the $\$ 8,000$ first home owners' grant, a measure projected to save $\$ 21$ million over the next three years. By delaying the commencement date of projects such as rail electrification, road capacity expansions, two health/hospital facilities and the replacement of the Convention Centre's plenary building, the budget bottom line improves by about $\$ 400$ million. However, none of this manages to avoid a previously projected $\$ 55$ million surplus being replaced by a forecast \$263 million deficit for 2011-12. Surprisingly, the Opposition had little to say, a point picked up by the local media and discussed below. Failure to reduce the operating balance was defended at a function this author attended, where the Treasurer promised that an $\$ 80$ million surplus in $2013-14$ would be followed by a huge $\$ 655$ million surplus the following financial year (Treasurer's address to the Public Administration Australia's [IPAA] Annual Economic Outlook Forum, 15 June 2011).

Table 1: South Australian Budget Projections as at June 2011

\begin{tabular}{|c|c|r|r|r|r|r|}
\hline & & $\begin{array}{r}2010-11 \\
\text { Estimated } \\
\text { Result }\end{array}$ & $\begin{array}{r}2011-12 \\
\text { Budget }\end{array}$ & $\begin{array}{r}2012-13 \\
\text { Estimate }\end{array}$ & $\begin{array}{r}2013-14 \\
\text { Estimate }\end{array}$ & $\begin{array}{r}2014-16 \\
\text { Estimate }\end{array}$ \\
\hline $\begin{array}{c}\text { Net operating } \\
\text { balance }\end{array}$ & $\$ \mathrm{M}$ & -427 & -263 & 114 & 80 & 655 \\
\hline Net lending & $\$ \mathrm{M}$ & -1821 & -1252 & -489 & -56 & 542 \\
\hline Net debt & $\$ \mathrm{M}$ & 3,217 & 3,825 & 4,098 & 4,213 & 3615 \\
\hline $\begin{array}{c}\text { Net financial } \\
\text { liabilities } \\
\text { To revenue }\end{array}$ & $\%$ & 94.4 & 95.6 & 95.8 & 96.3 & 88.5 \\
\hline
\end{tabular}

Source: Budget Paper 1, The Budget Overview, Government of South Australia, June 2011, p. 2. 
For their part, Labor's traditional allies in the union movement remained disgruntled, although there would be some reprieve. In the lead-up to the budget, Unions South Australia leader Janet Giles pleaded with the government to end its "absolute obsession with the Triple-A rating" (Advertiser, 13 April 2011; Australian, 4 June 2011). While this was never a prospect, public sector unions were no doubt pleasantly surprised to find, a week before his budget was due, Snelling announcing that holiday leave entitlements would be fully restored, costing the government $\$ 67$ million in previously announced savings. Less pleasing to the unions was his refusal to fully restore long service leave provisions or to renege on Foley's earlier budget's initiative to retrench public servants who could not be gainfully employed after twelve months on the "redeployment list" (Advertiser, 18 June 2011). While restoration of holiday leave entitlements bought some peace, unions made it known they wanted a new premier, backing the Left's Jay Weatherill.

\section{Labor's Leadership Question and the Opposition's Quietude}

During the autumn, focus sharpened on the question of how long Premier Rann would last. The February cabinet reshuffle represented, arguably, the Premier's last chance to rejuvenate his government. However, he was hamstrung by names the factions offered as ministers and by the fact that Foley wanted to remain in cabinet. Thus, the reshuffle fell well short of revitalising his government and few predicted it would stem the tide of voter dissatisfaction (Sunday Mail, 13 February 2011). On numerous occasions Rann has stated his intention to lead Labor at the next election, but few in his party accept this as a realistic proposition and, with the opinion polls pointing to the government's defeat, perhaps akin to that suffered by the New South Wales Labor government, the drums for change began to beat. Rann's supposed preferred date appeared to be sometime after his government's ten-year anniversary in March 2012, but it became noticeably apparent that the Right faction's preferred candidate, Attorney-General John Rau, started to appear frequently as representing the voice of the government (Weekend Australian, 28-29 May, 3-4 June 2011; Advertiser, 28 May 2011). While there was no evidence of the Premier preparing the way for an early exit, the poor polling suggested Rann's tenure was unlikely to see out the year. However, the problem for the Right faction was acute, for polls published in the Advertiser and Sunday Mail demonstrated very clearly that the public prefers the Left faction's candidate, Education Minister Jay Weatherill. Indeed, the question, "Who do you think should lead Labor to the state election in 2014?" showed voters opting for Weatherill ahead of the Premier, 40 per cent to 27 per cent, with John Rau languishing on a mere 11 per cent (Sunday Mail, June 2011). With Labor's primary vote plummeting on one occasion to well below 30 per cent (Advertiser, 20 April 2011) and at 30 per cent in consecutive Newspolls (Australian, 21 June 2011), the ghost of the New South Wales election no doubt haunted the Labor caucus. Discipline had been a hallmark of the Rann government, but when one exasperated backbencher, Leon Bignall, confessed in a radio interview that, "replacing Mr Rann with Mr Weatherill would be 'a solution to Labor's problems"," it became evident that a level of desperation informed conversation on this matter (Advertiser, 22 June 2011). While Bignall drew the ire of ministerial veterans, it is a fair bet he spoke for a growing number and, in all likelihood, across the factional divide.

With regard to the Opposition, the year began with The Advertiser leading with the headline, "Step to the Left - Redmond to shed conservative image" (6 January 2011). Opposition leader Isobel Redmond had articulated the not unreasonable view that younger voters perceive the party as dominated by "men in suits" and stressed that one 
of her objectives in the year ahead was to dispel this perception by stressing that, on social and environmental issues, her party was less conservative than Labor. Apart from the usual rhetoric condemning the budget as "breathtakingly bad", there was little policy to underpin her claim for the opposition's more progressive approach to environmental issues. The most the papers could report were her plans to halt urban sprawl by encouraging reforms to council planning. Perhaps as a consequence of the vagueness of Redmond's vision, The Advertiser began what appears to be a campaign to pressure her into announcing some meaningful policies. A feature of her predecessor, Martin Hamilton-Smith, had been his attempt to develop clear policy differences with Labor, a fact probably not going unnoticed in Liberal party ranks. Editorials and features by the Advertiser's most senior political reporter, Greg Kelton, essentially accused Redmond of policy laxity as the Opposition pursued the so-called, "small target" strategy (Advertiser, 2, 21 April; 14 May, 22 June 2011). Redmond signalled in May that she was preparing a series of "headland speeches" but this did not convince a restless Advertiser. In June the newspaper was again scathing, roundly criticising her failure to develop a plausible critique of the government's budget: "Ms Redmond failed spectacularly to take the fight to the Government [...] She has tried to make a virtue of having nothing to say [...] For any South Australian who was asked what the Liberal Party stands for in this state, the only possible answer today would be, 'I don't know" (Advertiser, 22 June 2011). Time will tell whether this is a harsh judgment. But should Labor change its leader and enjoy the customary "political honeymoon", then those with leadership ambitions in Redmond's party - of whom there are a number - are unlikely, given recent animosities, to remain supportive of her tenure.

\section{Prominent Policy Issues and Debate}

As part of former Treasurer Kevin Foley's response to the Global Financial Crisis (GFC), in December 2008 the government announced that it would sell harvesting rights for two rotations of all state-owned forests, with a possible third rotation in the richer forestry region of the state's south-east. This policy derived from Foley's December 2008 economic statement in response to the cut in Commonwealth GST, at which time, fearing the prospect of deeper budget deficits in the lead-up to the 2010 election, the Rann government reneged on its long-term commitment to "no further privatizations". Early in 2011 this policy was put into effect with the government's announcement of its intention to tender for the leasing of harvest rotations. This provoked a hostile reaction from those communities that most depend on forestry. In March, as the government prepared for the sale, which it expected would raise between $\$ 500$ to 700 million, about 3,000 citizens, accompanied by around sixty trucks with horns blaring, participated in a protest march, culminating outside parliament (Advertiser, 9 February and 5 May 2011). The government's commissioned report that had recommended the sale came under heavy criticism from forestry worker representatives for failing to take into account the value-adding benefit to the region of the forestry industry and for making many "basic errors". Clearly, there is widespread community anger over possible job losses and the prospect of harvest revenue no longer going into government coffers. Spokespersons for the timber industry claimed 5,000 jobs would be lost from a sector considered to be the driving force of the SouthEast economy. In refuting these claims, Snelling responded: "I would not have proceeded with this sale if I was not 100 per cent convinced that the jobs of southeast families were absolutely secure" (quoted in The Australian, 4 May 2011). 
As noted earlier, the Triple-A rating looms large in government consideration over how to rein in debt and bolster revenue. This logic of reducing current state debt failed to convince the communities depending on forestry for their livelihoods, but the stark reality is that the Labor party holds no seats in the state's forestry regions (Advertiser, 5, 31 March; 5 May 2011). An immediate windfall to the budget's bottom line is far too tempting to pass up, even in the face of apparently rational critique. A detailed study of the matter under the auspices of the Australian Senate's Rural Affairs and Transport References Committee found that little convincing evidence had been produced by the Rann government to support its claims that forestry industries and communities would not be negatively affected by the sale. The Senate Inquiry recommended "that the South Australian Government facilitate the timely release of the Regional Impact Statement relating to the proposed forward sale of South Australia's timber assets, as well as any relevant information that is currently, or comes to be, held by the South Australian Government" ("Sale of timber assets by the South Australian Government", The Senate, Commonwealth of Australia, 29 April 2011).

In early May, a eulogising editorial from The Advertiser (4 May 2011) said: "Hats off to the members of the South Australian Cricket Association for taking the brave decision in allowing for the redevelopment of the Adelaide Oval to proceed". The vote was a great relief for the government, given that it had campaigned for the oval's redevelopment against the Liberal party's plan for a new stadium. Had the vote gone the other way, the government would have confronted the messy business of legislating to overturn the "democratic process" of the Cricket Association. With some 80 per cent of members in favour, the question was raised by those who opposed the oval's redevelopment of why so-called "undirected" proxy votes were deemed automatically to favour the $\$ 535$ million project. The Cricket Association refused to release details of the vote, prompting former federal Labor MP, Rod Sawford, to observe: "You should be able to show your results and they should be accountable and in this case there is half a billion dollars of taxpayer dollars involved so it should be explained how 80 per cent was obtained" (Advertiser, 4 May 2011). Sawford also wryly commented on the unusual situation of 80 per cent in favour, but the returning officer declined to comment! Nevertheless, the supporters of the project, and they are many and powerful, rejoiced at the prospect of AFL matches coming to the city's heart. For government MPs the prospect of that event occurring in an election year no doubt buoys their flagging spirits. Less enthusiastic are the wealthy and well-heeled residents of North Adelaide, who fear noise and congestion on match day, and the Adelaide City Council, who fears that a fair share of car park revenue will not be forthcoming.

What to do with the Royal Adelaide Hospital featured during the 2010 election campaign? In April this hotly contested issue presented cause for future wrangling when the government reported what appeared to be a $\$ 1$ billion cost blow-out (The Advertiser, 5 May 2011). It depends how one views the cost of the project as a publicprivate partnership (PPP), and the difficulty of making an assessment of the real cost to taxpayers lying with the "commercial in confidence" dimensions to the deal the government has struck with Macquarie Bank. The Opposition is keen to stress the blow-out of "final" cost while the government sticks doggedly to the view that it will cost $\$ 1.78$ billion to build. This issue is likely to remain a point of contention for, as commentator, Professor Dean Jaensch, noted in his weekly newspaper column: "Essentially a PPP is a means for government to escape from a full process of transparency and financial responsibility" (Advertiser, 12 May 2011). 


\title{
Tasmania
}

January to June 2011

\author{
MEgAn AlesSANDRINI \\ School of Government, University of Tasmania
}

2011 has been unusually tumultuous for Tasmania. The delicate minority government survived the change in the Labor leadership but the new premier has faced considerable scrutiny, particularly on economic matters. The forestry industry reform agenda is contributing to a perception of declining economic prospects for which recent rescue packages have apparently been inadequate. The state is also facing skill shortages and while the unemployment level is not increasing, arguably this is more to do with a decline in the size of the labour force than economic health. When coupled with reduced GST payments arising from less consumer spending, state cabinet is facing some unenviable choices.

\section{State Leadership Switch: "The Only Certainty is Change"}

The power-sharing model piloted by then Premier Bartlett had begun to pay dividends by January, with sound working relationships in place with Greens leader Nick McKim. Premier Bartlett expressed a preference "to be consensus driven and to work with people" and the need to provide stable government where there are minority interests involved and avoid traversing "the brink of parliamentary chaos" (Mercury, 1 January 2011). Despite these optimistic remarks and the announcement of numerous impending developments for the state, David Bartlett resigned as premier on 24 January so he could spend more time with his young family, to be succeeded by Tasmania's first woman in the role, Lara Giddings. Premier Giddings has been a member of parliament for a total of eleven years, having first held a seat at the relatively young age of twenty-three. She brought to the role experience and demonstrated capacity in a number of high profile portfolios. Nevertheless, The Australian focussed on the incoming Premier's personal life for its front page headline on 25 January: "Leftist Lara still looking for Mr Right". It is possible that the focus on family was related to the reasons given by the outgoing premier for his resignation: a commitment to his family. Certainly, Premier Giddings seemed unconcerned about discussing her life with the media.

Speculation that David Bartlett was persuaded to step aside by the offer of support to gain a seat in Canberra was steadfastly denied. The new state Attorney-General has adamantly stated that he vacated the Premier's position so he could spend more time with his young children, and for no other reason. The media nick-name "Backflip Bartlett" had gained traction, and declining popularity measured through polls must surely have had some influence too. Bartlett's contention that Labor would be unlikely to govern in its own right for some time in Tasmania was reportedly interpreted by some as a betrayal of the Labor tradition and values, but could well be prophetic.

The Legislative Council election for the seat of Rumney held for twelve years by Lin Thorp, a minister for the ALP government, was fought hard. Education, Children's and Police Minister Thorp faced the ire of former Children's Commissioner Paul Mason who was not reappointed to his position and then stood against her for the seat of Rumney. This was preceded by a critical report authored by the Commissioner in 2010 who investigated the case of the abuse, neglect and prostitution of a twelve-yearold girl by her mother and step-father while she was a ward of the state. Criminal 
charges were laid against the pair; however Mason's report found the Department and the minister had failed to meet their legal obligations to the child.

Lin Thorp's ministerial responsibilities in the small cabinet were significant and represented a considerable workload. With one less ministerial hopeful to choose from, Premier Giddings would need to turn to the newer recruits to the ranks. Minority partners the Greens may have hoped they would be invited to provide another minister, but this did not occur. The Premier decided to reduce the size of cabinet instead, which she explained as a cost-cutting measure in the face of a looming tough state budget.

It was at this point that Attorney-General and former premier David Bartlett announced his retirement from parliament effective immediately. The impact of these events was summed up by Premier Giddings as "a terrible week for me and my government; I'm not going to gloss over it" (Mercury, 14 May 2011).

The re-shuffle saw increased responsibility being passed to the existing Greens ministers, and a re-ordering of ministries among Labor members, as well as several new entries to the ministerial ranks. Greens leader Nick McKim took over the education portfolio, while fellow Green minister Cassy O'Connor received Climate Change and Aboriginal Affairs portfolios. Michelle O'Byrne and David O'Byrne also acquired new workloads of Children; Sport and Recreation; and Police and Emergency Management respectively. New member Brian Wightman became Attorney-General and Minister for Justice, and Scott Bacon was appointed Minister for Hospitality, Veterans' Affairs and Tourism.

The EMRS quarterly survey conducted in late-May indicated that the Liberal party would have won 12 to 15 of the 25 lower house seats if an election had been held, but there was a strong 22 per cent group who were "undecided" as to which major party they would support. The fall in the popularity of the Labor and Green parties is unsurprising given the recent difficulties both have encountered while in government.

\section{Budget Blues: Basket Case or Legitimate State of a Federated Australia?}

In January, it became apparent that there would be a need to reduce costs of staffing and possibly make other cuts to state spending. This anticipated adjustment arose from a known reduction in GST revenue. While initially it was hoped that cuts would not involve frontline service providers such as police, teachers and health professionals, by February it was clear that the state's debt problems were considerable. The 52 per cent of the annual state budget spent on the employment costs of 24,000 state sector employees would need to be scrutinised with a view to making savings. Another innovative reform considered was the pooling of government-business enterprise [GBEs] financial arrangements, so that the more successful GBEs would be required to top up shortfalls of those recording losses. Treasury chief Martin Wallace announced this proposal in February, anticipating that this would relieve government from the all too frequent rescue payments to GBEs Aurora and Forestry Tasmania. Public sector job losses appeared to be inevitable and several unions responded to this in support of their threatened members.

In April Western Australian Premier Colin Barnett commented that Tasmania was an economic "basket case", receiving an unfair share of commonwealth funding at the expense of other states, but this was refuted. Saul Eslake, former ANZ chief economist and currently a member of Melbourne University's Grattan Institute, conceded that Tasmania had poor education retention rates and would face difficult economic circumstances for some time, but was not about to collapse. At a public forum, he noted that conditions had in fact improved since the 1990s (Mercury, 28 April 2011). The forum concluded with the Premier, the Leader of the Opposition and the Greens 
leader largely in agreement that the state had some major challenges to address but that there was certainly potential to be prosperous.

Inevitably budget cuts were going to be unpalatable, but the anger and sadness expressed when school closures were mooted was perhaps unexpectedly vocal and passionately expressed. Many of the twenty schools identified as being considered for closure were the hub of the small towns in which they were located, and parents expressed concern about the need to change arrangements for schooling, commuting, after school care and in some cases a need to relocate altogether. Newly-appointed Education Minister, Greens leader Nick McKim, met with an onslaught of protest and appeals for the closures to be reconsidered. As a result of copious feedback and comment on the proposed closures, the minister has now established a reference group including representatives from the union movement, parents and friends associations and principals, as well the state Social Inclusion Commissioner, and chaired by a leading business director. The difficult decisions for which the Premier had been willing to take responsibility will now be made on the basis of recommendations from a community-based reference group. Some may regard this development as falling into the category of "be careful what you wish for". The main complaint about the government's choice of schools for closure was that the criteria used were economic rather than social. The reference group is charged with identifying schools for closure on the basis of social as well as economic factors, to include retention rates and educational outcomes. There is no guarantee that these recommendations will meet with community approval any more than the previous ones.

\section{Parliamentary Reform at a Standstill for Now}

Proposed parliamentary reform to lift the number of seats in the lower house from 25 to 35 has been put aside by the government. In January the Tasmanian Constitution Society again raised the issue, commenting that David Bartlett's resignation as premier demonstrated the need to increase the numbers so the workload could be distributed thus allowing more time for work/ life balance. Leader of the Greens Nick McKim supported this reform, noting that "cutting the numbers in the House of Assembly has led it to being an appalling framework to make decisions [and] led to a very shallow talent pool from which to source ministers" (Mercury, 14 May 2011). The Premier however was unwilling to continue the reform process when facing such a dire budget, as the cost of ten more parliamentarians, expected to be in the region of $\$ 3$ million, would be difficult to justify in this climate of reduced government services and public sector redundancies.

\section{Forestry: the State Still Split}

It had become apparent that many Tasmanians had heard enough of the "for and against" debates and emotional point-scoring on forestry in Tasmania. Politically it could be argued that everyone's interests would be best served in bringing this historically lengthy and damaging battle to an amicable close. This is particularly clearly reflected in the statements from lobby group Our Common Ground, describing the forest peace negotiations as moving at a "glacial pace", (Mercury, 22 May 2011). Despite this, stakeholder groups have continued to argue on several fronts. The forestry policy wrangle has continued despite the impressive efforts of many involved with groundbreaking peace talks with former ACTU president Bill Kelty at the helm. These were intended to resolve the long-standing and economically damaging battles fought in the media and the forests of Tasmania and to pave the way for a positive united future based on co-operation and compromise. 
The new year saw reports that the federal government had advised Premier Bartlett they would not be prepared to fund the Tasmanian forest peace arrangements, a grave concern given the limited resources available to the state. Prime Minister Gillard was reported to be of that view that this was Tasmania's problem and Tasmania should therefore develop its own funding plan to ensure the progress of the initial Statement of Principles signed in October 2010.

Following a significant drop in revenue in 2010, Forestry Tasmania announced plans to shed fifty employees by the end of the 2010/11 financial year. This was expected to result in savings to the company of $\$ 2$ million a year, in the wake of a $\$ 7.9$ million loss last financial year. The job losses were expected to be mainly in the north at regional offices where the impact of the industry restructure will be felt directly. Gunns Limited has announced that it will end native forest logging, drawing its raw material from plantations. This restructure, a response to global trends and volatility in the industry, has been detrimental to the share price for Gunns, which fell to 48 cents in early February.

In mid-January, Gunns shed senior managers from their pulp mill project despite claims the project was still on track and continuing to seek a joint venture partner. Gunns has remained committed to the Tamar Valley Pulp Mill venture, but there is still wide community rejection. Gunns CEO Greg L'Estrange has claimed the project has been significantly reformed since initially proposed, but issues such as the level of treatment of effluent released into Bass Strait continue to be contentious. The CEO embarked on a campaign to win over project critics through direct contact, explaining the benefits of the project and noting in particular that "Gunns can no longer operate as though it need only satisfy commercial interest. We are a company operating within a social and economic context [...] [engaging in] open engagement with our supporters and critics" (Mercury, 10 February 2011).

Subsequently Gunns sold off numerous significant holdings of plantation forest to gather resources for the pulp mill roll-out. Several false starts in finding a joint partner to co-fund have delayed commencement. Premier Lara Giddings has explicitly ruled out state government involvement in funding the venture, either through direct funding or underwriting the venture, but would be prepared to assist with infrastructure support and concessions.

The Kelty-led peace process has sought to avoid involvement in the pulp mill debate, but this has been difficult when so much employment and forest industry activity is in the balance. Arguably the chance of the talks reaching resolution depends on acceptance that the planned pulp mill can be operated sustainably and without damaging waterways or the surrounding rural environment. Conflicting opinion on the commencement date for the planned moratorium on logging of high conservation-value forests caused further disagreement. The Premier claimed that such a moratorium could not commence until all parties to the statement of principles had reached agreement. Many were disappointed to see the Wilderness Society withdraw from the peace process over this issue.

May saw the publicly-aired development of a rift between government-owned enterprise Forestry Tasmania and Gunns Ltd, with CEO Greg L'Estrange labelling Forestry Tasmania as the corporate body with whom he had experienced the most difficulty. This statement to a House of Assembly select committee seemed to be based on conflicting priorities: while Forestry Tasmania was intent on saving jobs and benefitting the community of Scottsdale by retaining processing activity there, Gunns' 
bottom line seemed to indicate it would be better business to conduct the processing in their Bell Bay Mill.

The Gunns-owned Triabunna Woodchip Mill was closed at the cost of fifty jobs and twenty contractors, and came up for sale in June, attracting interest from some unexpected quarters. Initially it appeared the mill would be purchased by two environmentalist philanthropists, Jan Cameron and Graeme Wood, who wished to convert the site to a tourist venture. An industry consortium operating as Aprin Logging subsequently claimed their offer had been accepted, despite its being for a lower figure. Graeme Wood claimed at this point that the mill could not possibly survive in the current market, and that he personally expected it to fail. He stated: "If it goes through, we'll buy it for half the price when it goes broke in a year or two" (Mercury, 13 June 2011). Rumour flourished and it would be some months before the sale of the mill to the Cameron-Wood bidders would be confirmed. Gunns had already closed two native-forest woodchip mills, Long Reach and Hampshire, and put the Massey-Green Mill near Burnie on the market. This was in response to a collapse in the global market for woodchips, related to hardship following the recent earthquakes and tsunami in Japan.

\section{Affordable Housing}

The affordable housing scheme, although now restructured, continues to draw criticism from the opposition for being a waste of taxpayer funds, and from welfare organisations for falling short of demand. The experiment with outsourced management of the program was not as effective as envisaged, and the tender process is now administered by the department as before, and is managed in association with the federal government's National Rental Affordability Scheme [NRAS]. In February, Minister Cassy O'Connor expressed continued commitment to the development and provision of "assisted housing", commenting that this was beneficial to Tasmanians in need of housing but also to the Tasmanian building industry. Broad acre developments are now consigned to the past. There is an increased emphasis on sustainability and convenience for residents. New development sites are in inner-city locations, and utilise solar technology and sustainable building practices. Occupants of assisted housing who in the past had been isolated in suburban housing estates will now be centrally located and able to gain access to the services and amenities they need. Nevertheless the opposition has raised concerns about exorbitant construction costs. It is impossible to accurately predict costs of individual dwellings when they form a component of a larger development program. It remains to be seen if the Labor/ Green government is able to meet its target of 1,400 new affordable homes by June 2012 $<h t t p: / / w w w . m e d i a . t a s . g o v . a u / r e l e a s e>$. 


\title{
Northern Territory \\ January to June 2011
}

\author{
MiCKey DeWAR \\ The Northern Institute, Charles Darwin University
}

\section{Introduction}

The politics of the Territory never fail to surprise. The Federal government Intervention, restrictions on alcohol purchase, the construction of the Inpex onshore gas plant imminent, the rage of Alice Springs residents - all these were eclipsed by a new threat to the Territory way of life. The problem? Animal welfare.

\section{"A Bloody Business..."}

In April, the Northern Territory government advised that it was now too late to prosecute over a case of animal cruelty that had received national attention the previous year. In October 2010 the Ombudsman Carolyn Richards tabled a report to parliament of animal cruelty on Charles Darwin University's Mataranka Station where she said that that up to 800 head of livestock had "died an agonising death" of starvation and neglect (Sydney Morning Herald, 25 April 2011). Richards blamed both Charles Darwin University and the Northern Territory government for failing to monitor the situation and found the lack of prosecution "heartbreaking" (ABC Katherine, 8 April 2011). Opposition spokesman John Elferink alleged a government "cover-up" (Northern Territory News, 5 April 2011). Warren Snowdon, whose electorate of Lingiari includes Mataranka Station, said the situation was "an issue for the NT Government" (Sunday Territorian, 5 June 2011). Auditor-General Frank McGuiness disputed the number of deaths at a public hearing of the Council of Territory Cooperation, but popular opinion put the blame on the government.

The pastoral industry is important in the Northern Territory. An estimated 350,000 head of live cattle are exported to Indonesia each year, worth about \$200m (Sunday Territorian, 29 April 2011). The timing was unfortunate then when only a month or so later ABC Four Corners broadcast (30 May 2011) "A Bloody Business" which showed film footage of "gross, horrible abuse" in the slaughter practices in some Indonesian abattoirs. Territory cattlemen called for a ban on export to those abattoirs. The federal government extended this ban and all live cattle export was suspended until animal welfare could be guaranteed.

Primary Industries Minister Kon Vatskalis declared: "The NT Government does not condone any mistreatment or cruelty in our livestock industry". In view of the fallout from cruelty allegations at Mataranka Station the Northern Territory News received a "barrage of letters and text messages" from readers accusing the government of hypocrisy (4 June 2011). As the ban continued, increasingly individuals and industry groups voiced their dissatisfaction. The Northern Territory Cattlemen's Association CEO Luke Bowen met Minister Vatskalis and a delegation of Northern Territory pastoralists went to Canberra to plead their case. An emergency sitting of the Northern Territory parliament was called with bipartisan support for the lifting of the ban and a joint motion was sent to the Prime Minister and Indonesian government. The relief plan announced by Agriculture Minister Joe Ludwig on 27 June to allow cattle industry workers to access unemployment benefits, was not well received (although no one asked if such payments would also be subject to income management). 


\section{"Drinks As Usual..."}

The Territory government (and Opposition and federal government) consistently ruled out introducing a floor price for alcohol despite health experts and Greens Senator Rachel Siewert calling for this reform. The Australian, citing a Department of Justice former senior licensing and regulation policy lawyer Peter Jones, claimed the Northern Territory government policy had been watered down to "placate hotels" (19-20 March 2011). The Northern Territory News reported that the Labor Party received $\$ 300,000$ before the 2008 Northern Territory election although the Chief Minister "absolutely rejected" any suggestion that the donation had influenced policy-making (Northern Territory News, 23 March 2011). The News agreed that this must indeed be the case since the Opposition also supported the policy. The decision, however, was also popular electorally, at least in the News voxpop where a 54 per cent majority rejected the introduction of a floor price for alcohol (Northern Territory News, 24 March 2011).

But apparently retailers go where governments fear to tread. In Alice Springs IGA stores joined Coles and Woolworth to introduce a target floor price of $\$ 1.15$ per unit of $10 \mathrm{ml}$ pure alcohol and announced they would not restock once sales of cask wine had been sold (Northern Territory News 25 June 2011).

\section{Alice Springs — "Tsunami Of Crime..."}

Racial conflicts in Alice Springs dominated news reporting at the start of the year. Journalist Nicolas Rothwell opined bleakly that in "Alice Springs [...] Race relations are worsening and fear is rising on both sides" (Australian, 19-20 February 2011). The Opposition described it as a "Tsunami of crime". Alice Springs businesspeople formed "Action for Alice", to create and broadcast a series of television advertisements highly critical of the government's failure to resolve increases in property crime, showing lawless Aboriginal youth roaming the streets of Alice at night (Northern Territory News, 19 February 2011). The government deployed an additional 18 police officers to be located in Alice until the residents "feel safe again" (Northern Territory News, 1 March 2011).

The residents of the Aboriginal town camps and their visitors were held to be responsible for much of the criminal and antisocial behaviour. The federal Indigenous Affairs Minister Jenny Macklin reiterated the government's commitment to a $\$ 150 \mathrm{~m}$ program to transform the town camps. Alice resident and former Administrator Ted Egan asked: "Why is the government financing these people to be criminals in the town camps of Alice Springs?" (Australian, 5-6 March 2011). The biennial Northern Territory Parliamentary sittings took place at the end of March and about 200 people from the Action for Alice group rallied, calling for tougher penalties and youth curfews. The Emergency Response was also blamed for causing people from dry communities to come in to town to drink alcohol. (The Chief Minister Paul Henderson declined to address the protesters.) When Tony Abbott visited Alice, he agreed there were problems with law enforcement and said that he was considering the idea of a youth curfew (Australian, 30 April-1 May 2011).

\section{The Intervention}

The federal government's Intervention or Emergency Response continued to provoke controversy. The decision to extend income management, the quarantining of a portion of Centrelink payments for essentials, which previously only applied to Indigenous Territorians, to all welfare recipients, felt "humiliating", according to one of those affected (Northern Territory News, 15 March 2011). 
In April, Alice Springs Aboriginal activist Bess Price became the target of some very public abuse from Indigenous lawyer Professor Larissa Behrendt because of her support for the Intervention during an appearance on the ABC's Q\&A. Behrendt later emailed an apology. A couple of months later, Aboriginal elder and musician June Mills confronted Prime Minister Julia Gillard at Charles Darwin University calling for an end to the Intervention saying, "I'm homeless in my own country. All the Larrakia in this country are homeless." The Prime Minister responded by saying: "Nice to meet you. We're doing what we can on housing" (Northern Territory News, 10 June 2011). Bob Beadman, the retiring Territory government's Co-ordinator General for remote services was also critical of some of the contradictions inherent in the implementation of the policy. There is "an imbalance between what governments need to do and what people need to do for themselves", Beadman concluded (Australian, 18-19 June 2011).

The Prime Minister announced the Intervention Mark II to be implemented after six weeks of Aboriginal consultation with a focus on improving school attendance, economic development, tackling alcohol abuse and better housing and health. Northern Territory barrister Rex Wild QC, and co-author of the "Little Children are Sacred" report which sparked the Intervention in the first place, saw this as a case of history repeating itself: "So in 2011 they've identified those things yet again — bloody rocket science isn't it" (Northern Territory News, 23 and 24 June 2011).

\section{Arsenic Poisoning?}

The strange story of the arsenic poisoning scare from Mount Bundy Station, 130 kilometres south of Darwin, a pastoral and tourist business, illustrates some of the anxieties rural Territorians feel about the safety of their water supplies, as well as confirming that when things go wrong, Territorians blame the government.

Following the tragic death in an Adelaide hospital of seventeen-year-old Ben Witham from Mount Bundy Station with elevated levels of arsenic, testing revealed high levels in other long-term residents. The Northern Territory Coroner, Greg Cavenagh, ordered the immediate evacuation of about 140 Mount Bundy Station residents and tourists although the Health Department said that they had not been able to trace the source of the arsenic. The Northern Territory News carried a headline story that the government "knew of arsenic" and that this had been revealed in water reports more than three years ago. Tourists told stories of being woken at 2 a.m., handed water bottles and told to leave, comforted only by the advice that they could get a free arsenic test at the nearby Adelaide River Health Centre (14 June 2011).

The next events were contradictory. Four days later, the Coroner lifted the ban. The Environment Minister Karl Hampton announced at a public meeting in Adelaide River one month of free bore-water testing. In the course of events, Health Department staff were found to have misinterpreted test results and to have lost samples. Ben's grandfather was reportedly very angry at the story because Ben was in fact under treatment for acute leukaemia (Northern Territory News, 17 June 2011). No one was really sure what had happened.

While the Coroner understandably responded to what he believed was an emergency situation, the blame fell squarely onto the government. The Sunday Territorian summed it up in the words of an anonymous Adelaide River resident: "What we need is for the Government to admit they were wrong, cut the crap and apologise [...]" (26 June 2011). 


\section{Opposition}

If the government is a scapegoat, the Opposition has its own problems. In February the Northern Territory News published leaked emails allegedly revealing strong antipathy between leader Terry Mills and sometime leadership aspirant and member for Fong Lim, David Tollner. Mills had survived a previous challenge but the News suggested that the lead was narrowing. In something of an understatement, Mills commented: "The actions of the member for Fong Lim have not helped the cause at all" (Northern Territory News, 11 February 2011). The Country Liberals held a Central Council meeting in Katherine soon after, and emerged all smiles with renewed commitment to uranium mining. This was despite Mills' previously reported opposition to the Angela Pamela uranium mine in Central Australia (Northern Territory News, 14 February 2011).

Journalist Nigel Adlam's report that recent polling to test the popularity of Mills against Tollner suggests that for the Country Liberals, the leadership issue is not dead yet (Northern Territory News, 17 June 2011).

\section{Federal Politics...}

As usual, federal government politics weighed heavily upon Territory concerns. In February legislation to create a national nuclear waste dump at Muckaty, north of Tennant Creek, passed through the Lower House. The legislation was supported by the ALP Member for Lingiari, Warren Snowdon, but unsupported by Country Liberal Member for Solomon, Natasha Griggs, who joined the Independents and Greens in opposition to this. Chief Minister Paul Henderson said the site should not be chosen because the Territory was a constitutional "weak link" (Northern Territory News, 23 February 2011). Nuclear Free NT, a group dedicated to rejection of a nuclear waste dump, held a rally at Parliament House in Darwin on the day the National Radioactive Waste Management Bill was due to pass through the Senate. A speaker at the rally was Territory MLA Gerry McCarthy; Muckaty is located in his electorate of Barkly (Northern Territory News, 12 May 2011). When the Prime Minister visited Darwin, touring the new medical training centre at Charles Darwin University, former student, twenty-one-year-old Matt Haubrick jumped off a chair lunging at the PM to protest at the Muckaty waste dump. Haubrick commented later: "It didn't go so well [...] we may have surprised her a bit" (Northern Territory News, 10 June 2011).

Senator Bob Brown proposed a Private Member's Bill to enable Australian territories to make laws without the possibility of being overruled by federal parliament, causing concern for some conservative Labor MPs who feared the bill could lead to the territories legalising gay marriage. Treasurer Wayne Swan said the senators' concerns were "legitimate" (Northern Territory News, 4 March 2011). Chief Minister Paul Henderson shared these concerns: "I believe marriage is between a man and a woman" but supported statehood for the Territory, seeing Commonwealth power to overturn Territory legislation as "offensive" (Northern Territory News, 21 April 2011). A Senate inquiry headed by Northern Territory Senator Trish Crossin found that 95 per cent of submissions made to the committee supported the legislation (Northern Territory News, 6 May 2011). Henderson ruled out reintroducing euthanasia laws in the Territory. Opposition Leader Terry Mills agreed although he said that if elected as Chief Minister that he would allow a conscience vote.

The Northern Territory News dubbed it "The Darwin Solution" when it revealed government plans to build a 1,500-bed detention centre for asylum seekers at Wickham Point. Once completed, the News estimated Darwin's immigration detention capacity 
would be 2,900 - higher than on Christmas Island. Chief Minister Paul Henderson said that it was a federal issue but looked to "ensure there were positive outcomes for Territorians". The Bishop of Darwin, Eugene Hurley, warned that detention centres become "mental illness factories" (4 March 2011).

Inpex released its final 580-page Environmental Impact Supplement in April, modifying their original proposal of blasting a new shipping channel in the harbour by substituting dredging. The onshore gas project passed a number of critical stages in this period including environmental approval by both the Northern Territory and federal governments. Federal Environment Minister Tony Burke signed off on the offshore elements provided there were "strict environmental conditions" (Northern Territory News, 29 June 2011).

On 29 June the Australian and Northern Territory governments and the Northern Land Council signed an agreement paving the way for resolution of the long-running Kenbi Land Claim, first lodged in 1979.

Prime Minister Julia Gillard and eleven federal ministers faced Territorians in an open forum during the first Darwin Community Cabinet (federal Community Cabinet had been held in the Territory once before, in 2008, in Yirrkala). Apart from the live cattle ban, community members also raised concerns about the future of the Intervention and a nuclear waste dump at Muckety. The Prime Minister acknowledged that the Intervention "caused a lot of hurt and pain for indigenous Territorians" (Northern Territory News, 30 June 2011).

\section{Territory Roundup}

The First Nations political party led by Aboriginal activist Maurie Ryan received recognition from the Northern Territory Electoral Commission. Ryan signalled his intention to stand for Lingiari in the next election, a seat he unsuccessfully contested in 2007.

There were minor reactions to the Northern Territory Electoral Commission's proposed boundary shakeup and name changes although some residents were reportedly horrified to be moved out of the seat of Fannie Bay into Fong Lim (held by the Opposition's David Tollner). This could be because Michael Gunner (ALP) holds Fannie Bay but it could also be because of the change of name - Fannie Bay is one of Darwin's most prestigious suburbs.

The statehood cause continued, largely with indifference from citizenry but low-key bipartisan support, with the announcement of a program of constitutional conventions in 2012 and 2013. Elections for seventy-five delegates will be held on 24 March 2012 in conjunction with local government elections. A contrary view was argued bleakly by Nicolas Rothwell in The Australian, for an "emergency administration, a royal commission into the Darwin regime's financial management and a reshaping of the Territory: the capital turned into a city-statelet, and the hinterland declared a zone of special commonwealth responsibility [...]" (16-17 April 2011).

Environmental issues remained at the forefront. After years of indecision, in February container deposit legislation, largely the brainchild of Independent MLA Gerry Wood, received bipartisan support. In April, the Environment Centre and local fishermen expressed concern at spillages at the East Arm Wharf: "Any fish that swims about in that crap can't be safe to eat" (Northern Territory News, 30 March 2011). The News detailed a string of disasters at the Port including copper concentrate and iron ore spills, crane accidents and staffing issues. The CEO of the Darwin Port Corporation, Robert Ritchie, was moved to an office in the Chief Minister's Department. The Northern Territory News editorial attributed the primary reason for his move away 
from the Port Corporation to his inability to treat staff fairly, although columnist Nick Calacouras suggested Inpex also had concerns about Port safety (10 and 11 April 2011). The News also noted that the Darwin Port Corporation is expected to face prosecution for a copper concentrate spill in 2010 following an investigation announced by Environment Minister Karl Hampton (Northern Territory News, 12 April 2011).

There were no surprises in the budget. It was classic Labor. More spending on health, education, police and infrastructure with additional funding for land release including affordable home and land packages. According to Treasurer Delia Lawrie: "We made a deliberate decision to step into deficit to protect the economy" (Northern Territory News, 3 May 2011).

\section{Conclusion}

For Labor the partnership in government with Independent Gerry Wood has proved surprisingly stable. The Opposition is having a little more trouble keeping it together. Still, it is difficult for the government not to end up getting blamed for everything. Despite their distancing from federal Labor on the live export ban, some of the party association does stick. The next election is due to take place in August 2012. Despite the criticism, the government is travelling better than might be expected, but will it be good enough?

\section{January to June, 2011 \\ SCOTT BRENTON \\ University of Melbourne}

Australian Capital Territory

As Labor governments across the country churned leaders and new Liberal premiers came to office, Australian Capital Territory Chief Minister Jon Stanhope became the longest-serving head of government still in power, and more significantly, became one of the few political leaders to choose a time for his own departure. Stanhope anointed his deputy, Katy Gallagher, as his successor and said that, while he believed that he could win the next election, Gallagher had a better chance of increasing Labor's vote and needed time to establish herself and her government before the poll (Canberra Times, 10 May 2011). Stanhope was the longest-serving chief minister, having led the Labor party for twelve years and an unprecedented three consecutive election victories, which included winning elusive majority government for the first time after the 2004 election. The Canberra Times declared: "Stanhope's single most impressive legacy has been in shepherding self-government in the territory from its (occasionally) unruly juvenile stage when he came to power in 2001 to full maturity" (10 May 2011).

Stanhope's strong commitment to human rights included the passage of Australia's first Human Rights Act in 2004, exposure and criticism of the Howard government's anti-terrorism legislation, repealing anti-abortion laws, constructing the nation's first human-rights compliant prison, and recognition of same-sex relationships, which once again raised the ire of the federal government. Most criticism centred on his leadership style and perceptions of abrasiveness and arrogance, while his handling of the Canberra bushfires of January 2003, could have cost him office had a no-confidence motion been 
successful. Prior to entering the assembly, Stanhope worked as federal AttorneyGeneral Michael Lavarch's chief of staff, and was instrumental in crafting native title legislation to give effect to the High Court's Mabo decision (Canberra Times, 10 May 2011). Thus it was fitting that Stanhope's vacant seat in the assembly was filled by the Australian Capital Territory's first elected Indigenous member, Chris Bourke, on a countback of votes from the previous election. Bourke was a local dentist and was regarded as a possible future minister (Canberra Times, 31 May 2011).

New Labor leader Gallagher, who was elected unopposed by caucus, opted not to fill Stanhope's ministerial position. While many other jurisdictions have only recently seen female heads of government, Gallagher become the third woman to lead the Australian Capital Territory government, after the assembly confirmed her position in a vote, which is also unlike any other Australian jurisdiction. For the Greens, this meant signing a new parliamentary agreement under a new chief minister, but they did not demand any drastic changes (Canberra Times, 12 May 2011). Another split in the party was, however, exposed as Speaker Shane Rattenbury, claiming the backing of national party leader Senator Bob Brown, argued that the Greens should claim the vacant cabinet position, but he was overruled by convenor, Meredith Hunter, and fellow member Amanda Bresnan (Canberra Times, 17 June 2011). Instead Gallagher retained all the continuing ministers and reshuffled the portfolios as follows:

- Katy Gallagher: Chief Minister; Minister for Health; and Minister for Industrial Relations.

- $\quad$ Andrew Barr: Deputy Chief Minister; Treasurer; Minister for Economic Development; Minister for Education and Training; and Minister for Tourism, Sport and Recreation.

- Simon Corbell: Attorney-General; Minister for the Environment and Sustainable Development; Minister for Territory and Municipal Services; and Minister for Police and Emergency Services.

- Joy Burch: Minister for Community Services; Minister for Multicultural Affairs; Minister for Ageing; Minister for Women; Minister for Aboriginal and Torres Strait Islander Affairs; and Minister for the Arts.

Once again, factional equality in cabinet between the Left and Right was retained despite the Right's majority in caucus, but three of the four ministers are based in the central and north-eastern electorate of Molonglo, while there are no ministers from the north-western electorate of Ginninderra. Ambitious and influential member of the Right, Andrew Barr, settled for the deputy position (the first openly gay politician in Australia to hold a leadership position) but was pleased to take the treasury portfolio (Canberra Times, 10 May 2011).

\section{New Government, New Public Service}

Prior to his resignation, Stanhope foreshadowed a significant restructuring of the Australian Capital Territory public service, based on the recommendations of a review by Allan Hawke, a former Defence Secretary (Canberra Times, 4 February 2011). Gallagher's portfolio reshuffle reflected the creation of nine directorates - chief minister and cabinet, treasury, community services, economic development, education and training, environment and sustainable development, health, justice and community safety, and territory and municipal services - with each reporting to only one minister. Hawke's review, Governing the City State: One ACT Government-One ACT Public Service, recommended city-centred governance more akin to a local council than a state government, with the government pledging no cuts to the 20,000-strong 
workforce and the construction of a new $\$ 300$ million office complex in Civic for the entire public service (Canberra Times, 16 February 2011).

Hawke's six-month, 345-page review contained a number of other recommendations that the government declined to comment on or immediately adopt. As progress on an enterprise bargaining agreement between the government and ACTION bus drivers stalled, Hawke suggested that privatisation may be an option, arguing that private bus operators were more than twice as efficient as the public operator (Canberra Times, 17 February 2011). Hawke also recommended an amalgamation of the University of Canberra and the Canberra Institute of Technology, prompting cautious reactions from both institutions (Canberra Times, 17 February 2011). Education Minister, Andrew Barr, announced that the government would begin investigating options for collaboration between the university and institute, with a preference for a merger (Canberra Times, 18 April, 23 May 2011).

\section{Catholic Health Care Less than Charitable}

An assembly committee inquiry supported the construction of a new hospital in north Canberra, after the government's $\$ 77$ million proposal to purchase Calvary hospital from the Catholic health care provider Little Company of Mary collapsed. Committee members, Labor backbencher Mary Porter and Greens member Amanda Bresnan, recommended that the government should either build a new 400-bed acute hospital and convert Calvary into a sub-acute facility, or build a new 200-bed sub-acute hospital and add 200 beds to Calvary (Canberra Times, 1 April 2011). Liberal committee chair, Steve Doszpot, dissented while the Little Company of Mary argued that they should continue to provide acute services, such as emergency, maternity, elective surgery and intensive care (Canberra Times, 1 April 2011). The healthcare provider then allegedly threatened legal action on the belief that their lease arrangements granted the exclusive right to operate an acute care hospital in north Canberra (Canberra Times, 14 April 2011). Gallagher indicated that she was unwilling to proceed with constructing a new hospital under the cloud of legal action, while Stanhope refused to be cowed by threats (Canberra Times, 19, 20 April 2011). The two sides finally agreed to a $\$ 792$ million deal to upgrade Calvary with 200 extra beds and build a new 200-bed sub-acute hospital elsewhere in north Canberra, with the government retaining ownership of assets built in the upgrade (Canberra Times, 29 April 2011). Gallagher conceded that legal threats (which the Little Company of Mary denied making) were a factor in the government's decision to offer concessions, but welcomed a clearer definition of the roles of the two health providers as part of the deal (Canberra Times, 29 April 2011).

\section{Gallagher's Last Budget}

While she may not have known it at the time, Gallagher delivered her last budget as Treasurer, announcing a $\$ 100$ million turnaround in the bottom line for 2011-12, and forecasting a return to surplus in 2013-14 (Canberra Times, 4 May 2011). A surplus of just under \$20 million was predicted for the 2010-11 financial year, thanks to a secret $\$ 77$ million settlement with News Corporation and the decision not to proceed with a $\$ 174$ million mental health facility in Symonston (Canberra Times, 4 May 2011). The government proposed $\$ 266$ million in new spending over the next four years, to be offset by $\$ 216$ million in savings, including an extra $\$ 33$ million to be cut from public sector agencies' operating costs and voluntary redundancies to allow for modest growth (Canberra Times, 4 May 2011). Of longer term concern was the continuing fall in GST revenue, with the Commonwealth's share of the Australian Capital Territory's budget decreasing from 47 per cent to 39 per cent in just two years. 
Much of the new spending was directed towards Gungahlin, which is the fastest growing part of Molonglo, and incidentally also the electorate containing three government ministers and is predicted to be the electorate where a seat is most likely to change between the parties (Canberra Times, 4 May 2011). Liberal opposition leader Zed Seselja focused on cost-of-living pressures on families, and criticised spending $\$ 432$ million on a new government office block and asked why the $\$ 800$ million for the Calvary deal was not allocated in the forward estimates (Canberra Times, 5, 6 May 2011). A month later it was also revealed that the government was preparing to use taxpayers' money to compensate pokies clubs, if the federal government mandated the installation of betting pre-commitment technology (Canberra Times, 3 June 2011). The Australian Capital Territory Labor party owns four clubs, which operate 488 poker machines, netting $\$ 14$ million in revenue in 2009-10 and donating $\$ 662,000$ to the party (Canberra Times, 3 June 2011). Gaming Minister Andrew Barr indicated that he expected financial support from the federal government.

One of the most controversial measures was the change-of-use property charges, which had been costing the government up to \$20 million a year (Canberra Times, 27 April 2011). The Greens supported the changes after securing eco-friendly concessions, while industry groups and the opposition warned that higher fees and increased property prices would be borne by buyers (Canberra Times, 27 April 2011). After his resignation, Stanhope broke with tradition and disclosed that cabinet had split three-to-two in approving the changes (Canberra Times, 12 May 2011).

\section{State of the Territory's Status}

The federal Labor caucus initially agreed to support a Greens' bill to give the federal parliament the ability to veto territory laws rather than the current arrangements where the executive had that right (Canberra Times, 2 March 2011). Fearing that it could lead to same-sex marriage in the Australian Capital Territory (even though marriage is constitutionally under the purview of the federal government), a group of right-wing senators reportedly demanded that the prime minister reconsider and the bill was sent to a committee for further consideration (Canberra Times, 3 March 2011). While ACT Labor and the ACT Greens supported the bill, the Canberra Liberals urged their federal counterparts not to pass the bill, arguing that it reflected a piecemeal approach (Canberra Times, 11 March 2011). While the majority of the members of the Senate's Legal and Constitutional Affairs Legislation Committee recommended that the bill be passed, two Labor senators joined with five Liberals in dissenting (Canberra Times, 6 May 2011). The bill is due to be introduced into parliament in September, and the Greens will hold the balance of power in their own right in the new Senate.

\section{Criminal Justice}

The government decided to continue with weekend detention where approximately fifty criminals were imprisoned each weekend, despite no other Australian jurisdiction doing so (Canberra Times, 1 January 2011). Meanwhile, Health Minister Katy Gallagher and Chief Minister Jon Stanhope supported a needle exchange program in the territory's new prison to curb high rates of hepatitis $\mathrm{C}$ infections, despite concerns from prison staff (Canberra Times, 5, 6 January 2011). Former independent Heath Minister Michael Moore was commissioned to lead another report, prompting criticisms from the Liberals that he was not objective and was an advocate for the program (Canberra Times, 8 April 2011).

The Australian Capital Territory's controversial provision allowing judge-alone trials came to an end in relation to specific serious crimes, when the Greens decided to 
support the government's reforms, despite criticisms from the Law Society of the Australian Capital Territory (Canberra Times, 20 June 2011). Australian Bureau of Statistics' figures revealed that about 65 per cent of defendants were found guilty in the Australian Capital Territory, which was the lowest rate in Australia (Canberra Times, 28 June 2011). There have been a number of high- profile cases where people accused of serious crimes have opted for judge-alone trials and been exonerated, although the government denied that securing more convictions was the motivation, while the Greens supported a strong role for juries and community judgements (Canberra Times, 20 June 2011).

The government, again with the support of the Greens, also moved to address the backlog in the Supreme Court by allowing the Magistrates Court to hear most bail applications (Canberra Times, 14 February 2011). The Greens were less supportive of the government's reforms to increase the jurisdiction of the Magistrates Court to crimes where the penalty is five years in gaol, and to remove the choice of having matters heard in the Supreme Court in front of a jury (Canberra Times, 12 March 2011). The Australian Capital Territory Bar Association and Law Society supported the Liberals' proposal to allow prosecutors to choose whether to try the case in the magistrates or supreme court, while the Bar Association continued to call for the appointment of a fifth full-time supreme court judge (Canberra Times, 25 April 2011). The Law Society of the Australian Capital Territory also expressed concern about delays in Supreme Court and civil and administrative tribunal judgements, but Attorney-General Simon Corbell said it was a "matter for the courts" (Canberra Times, 26 February 2011).

\section{Electoral and Party Matters}

The government moved to amend legislation requiring all government campaigns valued at more than $\$ 40,000$ to be independently assessed, and to allow appointments of independent reviewers to be approved by a simple majority of assembly members, rather than a two-thirds majority (Jon Stanhope Media Release, 6 January 2011). The two-thirds majority requirement meant that the Liberals had to approve, rather than just the Labor and the Greens. The government introduced legislation to change the way that some casual vacancies for assembly seats are filled, allowing for the assembly to appoint a replacement member from the same party if no previous candidate from the party contested the recount of ballots from the previous election (Simon Corbell Media Release, 31 March 2011). Other minor changes based on the Australian Capital Territory Electoral Commission's report on the 2008 election were also proposed, and all changes were referred to the Standing Committee on Justice and Community Safety to enable assembly consideration and public consultation. The Electoral Commissioner also suggested that two Gungahlin suburbs be transferred from the electorate of Molonglo to Ginninderra, while a Gungahlin community group wanted the entire district of Gungahlin included in a new seven-member Ginninderra electorate, leaving Molonglo with five members (Canberra Times, 5 May 2011). The Australian Capital Territory Redistribution Committee found the group's proposal too radical.

The Liberals introduced a private member's bill to cap donations to political parties at $\$ 50,000$ in a single financial year, retrospectively dated to prevent a rumoured donation from the Labor clubs to the Labor party (Canberra Times, 30 June 2011). The Greens reserved their position but seemed open to the concerns, and received only $\$ 152,681$ in donations in 2009-10, compared to Labor's \$967,619 and the Liberals' $\$ 405,042$ (The Canberra Times, 30 June 2011). The Liberals finished the financial year owing \$141,664, including a \$136,000 bank overdraft, while ACT Labor received 
more than $\$ 650,000$ from its Labor Clubs and poker machine operations (Canberra Times, 2 February 2011). The Liberals' membership figures were also unhealthy, and while not publicly released were estimated to be between 500 and 700, with the Greens threatening to overtake them with a rumoured 530 members (Canberra Times, 16 June 2011). Labor also refused to divulge its numbers, but boasted that it was more than the Liberals and Greens combined, which was estimated at about 1,250 members. 